Portland State University

PDXScholar

$1-1-2011$

\title{
Chinese Merchants and Race Relations in Astoria, Oregon, 1882 - 1924
}

Aaron Daniel Coe

Portland State University

Follow this and additional works at: https://pdxscholar.library.pdx.edu/open_access_etds Let us know how access to this document benefits you.

\section{Recommended Citation}

Coe, Aaron Daniel, "Chinese Merchants and Race Relations in Astoria, Oregon, 1882 - 1924" (2011). Dissertations and Theses. Paper 422.

https://doi.org/10.15760/etd.422

This Thesis is brought to you for free and open access. It has been accepted for inclusion in Dissertations and Theses by an authorized administrator of PDXScholar. Please contact us if we can make this document more accessible: pdxscholar@pdx.edu. 
Chinese Merchants and Race Relations in Astoria, Oregon, 1882 - 1924

by

Aaron Daniel Coe

A thesis submitted in partial fulfillment of the

requirements for the degree of

Master of Arts

in

History

Thesis Committee:

David Johnson, Chair

Carl Abbott

Katrine Barber

David Horowitz

Portland State University

(C)2011 


\begin{abstract}
A large wave of Chinese immigrants came to the United States in the second half of the nineteenth century. Employment, mainly in the salmon-canning industry, drew thousands of them to coastal Astoria, Oregon. Taking the period between the first Chinese Exclusion Act in 1882 and the Immigration Act of 1924, this thesis focuses on the Chinese merchants in Astoria and their importance for our understanding of race relations in the town during these years. Specifically, the merchants help to make sense of how the Chinese related to the local white population, as different sources suggest different trends of amiability and hostility. Newspapers testify that local Chinese gained acceptance during the period, going generally from vilified outcasts to respected members of the community. Immigration case files, however, show that officials displayed little resistance to Chinese in the early exclusion years, but worked harder to deny Chinese applications toward the end of this period. So, from one body of records it seems that white Astorians grew more tolerant of Chinese during these years, while the other document set shows a rise in conflict with the immigrants. This apparent contradiction can be reconciled by considering the demographic changes in the Chinese immigrant community during this period, along with class biases and the role of merchants in immigration and social interactions.
\end{abstract}




\section{Acknowledgments}

This paper was a long time in the making, and I am indebted to a plethora of people for keeping it alive in direct and indirect ways. First, I want to thank my parents for their patient and loving support, without which I would not have been able to pay so much in tuition and miscellaneous fees. My uncle Steve deserves credit for defining my mid-thesis break as a nuclear lay-up. I also want to generally thank my friends and relatives, especially my sixteen or so housemates over the past few years, for putting up with my taciturn distractedness and depressive unenthusiasm.

Thanks to Kara Blied and Shannon Hannon for the lattes; Manuel Herrera for letting me observe his oral defense; Melissa Johnson for the sweet corner desk and the extra screws that somehow came with it; Amanda Larsen and Rachelle Webster for persistently asking about my paper; Leisha Adams for agreeing never to ask about it; Duncan Law for answering my emails; the friendly archivists at the National Archives of Seattle, State Archives, Clatsop County Historical Society, and Oregon Historical Society for all the research help; Joe Tysoe and Cirse for giving me places to stay in Seattle while I mined the archives there; Portland State's Food for Thought cafeteria workers for not closing on time and providing me a place to write my acknowledgments page; Leah Wagner for offering me a well-lit workspace for a change; Alex Selby for providing a desk to work and pretend I have a real job; Manuel, Melissa, Len Neiberg, Mike Pacchione, Eric Nelson, and other present and 
former graduate students for commiserating; and Arlin Migliazzo for starting me on the path to Portland State in the first place.

This thesis is also the result of considerable time and energy on the part of my professors, particularly David Johnson and Katy Barber, who both played a major role in the development and production of my thesis, and whose guidance, pep-talking, and thoughtful feedback helped me to endure my work and stay grounded in reality. There is about a zero percent chance that I would have completed this without you. 
Table of Contents

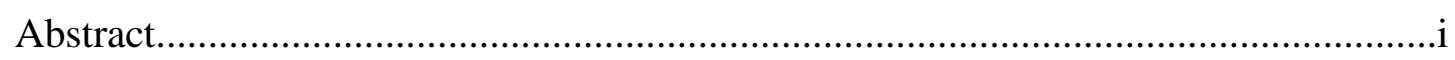

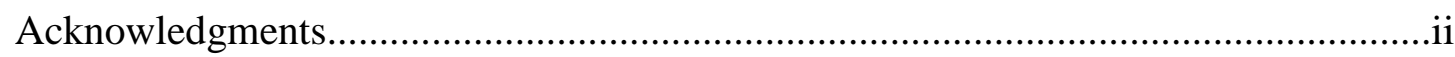

Chapter One

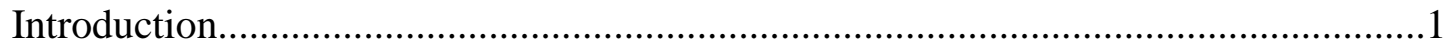

Chapter Two

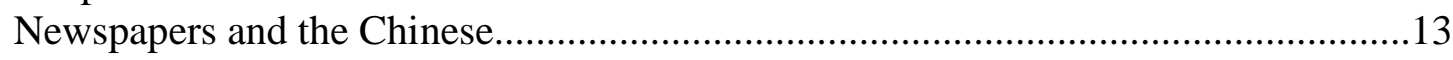

Chapter Three

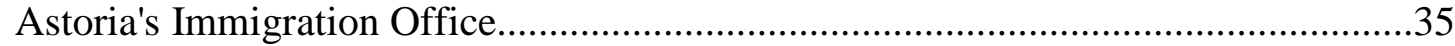

Chapter Four

Merchant Firms, Immigration, and Race Relations............................................52

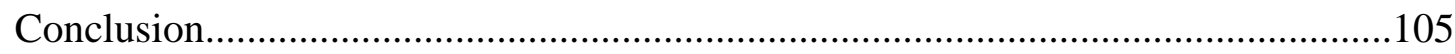

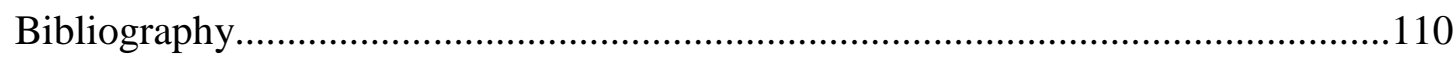


Chapter One - Introduction

In the records of Astoria, Oregon, two trends emerge regarding white-Chinese relations during the period 1882 - 1924, between the first Exclusion Act and the implementation of a national-origins-based quota system. First, there is an apparent increase in Chinese social acceptance and integration; this trend is exemplified in the local newspapers. Over the same period, Chinese immigration case files display increasing efforts to prevent Chinese from entering and remaining in the United States. So, Chinese endured locally less and less discrimination during this period according to one set of records but rising levels of it according to the other. The conflict of these two trends can be reconciled by considering class distinctions among Chinese immigrants and the white population's bias in favor of successful merchants. News accounts consistently treated Chinese merchants better than laborers, while the case files likewise show officials making fewer problems for successful merchants in the immigration office. From this perspective the two sets of records actually show continuity, demonstrating that class could be as important as race for Chinese immigrants.

The connection between the news accounts and the immigration files is important because it bridges the gap between immigration policy and popular sentiment. It also brings together the legal and social histories of Chinese immigrants in the United States, which are often treated separately. Additionally, it highlights the 
role of Astoria's local Chinese merchants, who have not received much attention from scholars up to this point.

The Chinese population in Astoria changed significantly between 1882 and 1924, most importantly in terms of its class makeup. At the beginning of the period, laborers vastly outnumbered merchants and the latter had very little local business history. In the ensuing four decades, the laboring population dwindled while successful merchants built families along with social and trade networks. Moreover, the decline in the Chinese population made the merchants, now well-known, appear less threatening and newsworthy, and the increasing proportion of the respectable merchant class generated more positive media coverage. At the same time, merchant status was one of the primary criteria for Chinese to enter the United States, and Chinese firms' expanding operations complicated the process of weeding out false merchants. So, the situation appears one way or the other depending on which part of the Chinese experience a source emphasizes, although the overarching story is the same.

Part of the context of white-Chinese race relations stems from the history of Astoria itself. Although the town remained small until the early 1880s its history was marked by cross-cultural connections and a degree of regional significance. Trading networks of fur-trappers, which western historian Carlos Schwantes calls "the first large-scale corporate enterprise in North America," infiltrated the Pacific Northwest around the beginning of the nineteenth century, and John Jacob Astor's Pacific Fur 
Company established an outpost near present-day Astoria in $1811 .^{1}$ Indian tribes like the Chinook, Clatsop, and Wahkiakum traded food and furs with the earliest European Americans and helped them to navigate the dangerous sand bar at the mouth of the Columbia River. This was a relatively friendly interaction in the context of later nineteenth-century Oregon's contentious race relations, which included bloody nativewhite conflicts and a protracted debate over the presence of slavery and African Americans. Chinese met similar resistance upon entering the Columbia Basin in the 1870s, but in Astoria the hostility was tempered by their essential economic contributions, especially in the fish-canning industry.

The salmon-canning boom in Astoria from about 1874 to 1887 significantly bolstered the city's growing regional prominence. ${ }^{2}$ White settlers unaffiliated with the trappers began arriving in the 1840s; the town gained the first U.S. post office west of the Rockies in 1847 and the first U.S. customs house in $1849 .{ }^{3}$ It became the seat of Clatsop County in 1854 and supported a thriving lumber industry after the Columbia River's first sawmill was built there in $1844 .^{4}$ Astoria's first salmon cannery was built in 1874 , and the town soon became the world's largest salmon producer. ${ }^{5}$ Five

\footnotetext{
${ }^{1}$ Carlos Arnaldo Schwantes, The Pacific Northwest: An Interpretive History, revised and enlarged ed. (Lincoln, Nebr., 1996), 62. James P. Ronda provides a detailed account of the fur trappers' exploits in and around Astoria in Astoria and Empire (Lincoln, Nebr., 1990).

${ }^{2}$ Chris Friday, Organizing Asian American Labor: The Pacific Coast Canned-Salmon Industry, 1870 1942 (Philadelphia, 1994), 56 - 58.

${ }^{3}$ Karen L. Leedom, Astoria: An Oregon History (Pittsburgh, Pa., 2008), 36 and 42; Marie Rose Wong, Sweet Cakes, Long Journey: the Chinatowns of Portland, Oregon (Seattle, 2004), 150 - 151.

${ }^{4}$ Leedom, Astoria, 38.

${ }^{5}$ Ibid., 118; Sarah L. Steen, "Expanding Context: A Look at the Industrial Landscapes of Astoria, Oregon, 1880 - 1933" (M.A. thesis, Portland State University, 2009), 39 - 41; Schwantes, The Pacific Northwest, 202. Steen asserts that by 1888, Alaska had actually surpassed Astoria, and the rest of the
} 
canneries dotted the area by 1876 and two dozen by the mid-1880s. Local canning declined after the late 1880 s as overfishing led much of the industry to relocate to Alaska and Washington's Puget Sound, but Astoria's population still grew fivefold from 2,803 in 1880 to 14,027 in 1920 , before fire devastated the core of its downtown in $1922 .^{6}$

Turn-of-the-century Astoria included a large number of immigrants, whose presence was amplified by geographic and economic concentration. The Finns, who became the town's largest immigrant group, worked primarily as fishermen and tended to live in Uniontown on the western side of town along the Columbia. Swedes, Danes, Norwegians, and Austrians also played large roles in the fishing and timber industries, with different ethnicities tending to concentrate in different types of work. ${ }^{7}$ In the mid 1870s, cannery jobs drew Chinese, and they soon became the largest nonwhite population in the city. Precise numbers are difficult to calculate due to the high itinerancy rate of Chinese workers at the time, the seasonal nature of the canning industry, and the questionable accuracy of census records, but the 1880 census listed

Columbia River, in canned salmon production. Still, Steen affirms Astoria's significance in the industry, saying that the town's fishing and canning operations "set a template" for the rest of the Pacific Northwest. According to Schwantes, Puget Sound's salmon output also outstripped that of the Columbia by 1895 .

${ }^{6}$ Friday, Organizing Asian American Labor, 56 and 58; Federal Writers Project, The Oregon Trail: The Missouri River to the Pacific Ocean (St. Clair Shores, Mich., 1972), 159; Riley Moore Moffat, Population History of Western U.S. Cities and Towns, 1850 - 1990 (Lanham, Md., 1996), 206. Peakseason figures for 1880 are closer to 6,000. The Oregon Trail states that Astoria's population had climbed past 15,000 by 1922, and according to Riley the number had dipped to 10,349 by 1930 .

${ }^{7}$ Vera Whitney Gault, A Brief History or Astoria, Oregon 1811 - 1900 (Astoria, Ore., 1982), 13; Steen, "Expanding Context," 74; Courtland L. Smith, Salmon Fishers of the Columbia (Corvallis, Ore., 1979), 27. 
nearly three thousand in and around the city. ${ }^{8}$ This number declined with the canning industry; after 1900 only a few hundred Chinese resided in Astoria, though they remained a visible minority in the first few decades of the century.

The first chapter of this thesis focuses on attitudes toward Chinese, as well as their social integration, as expressed in local newspapers. The papers show a pattern of growing amiability between Astoria's white and Chinese populations between 1882 and 1924. Of special importance is the content and style of papers during the period, which differed markedly from today, as well as the popularity and local background of the news media. Nineteenth-century editors embellished freely with fabricated details, willing even to print contradictory material. They melded advertisements, opinions, rumors, and events together with a single tone. As journalist Edwin L. Shuman explained in 1894, "Truth in essentials, imagination in non-essentials, is considered a legitimate rule of action in every office. The paramount object is to make an interesting story." ${ }^{9}$ University of Illinois professors Kevin Barnhurst and John Nerone agree that nineteenth-century papers in the United States were "multivocal"

\footnotetext{
${ }^{8}$ Friday, Organizing Asian American Labor, 56 - 57. According to Friday's numbers from the Clatsop County census, there were 2,122 Chinese in the city limits, plus 727 in Upper Astoria, which was originally separated from the rest of the town by a small bay and not subsumed by the city until 1891 . This makes a total of 2,849 Chinese. See also Smith, Salmon Fishers of the Columbia, 23; Smith tallies 2,045 Chinese in Clatsop County in 1880, but according to his figures this still amounted to 29 percent of the county's population.

${ }^{9}$ Edwin L. Shuman, Steps Into Journalism: Helps and Hints for Young Writers (Evanston, Ill., 1894), 123, quoted in Michael Schudson, Discovering the News: A Social History of American Newspapers (New York, 1978), 79.
} 
and "carried incommensurable content," and "did not hold to modern notions of objectivity based on facts." 10

In contrast to the current struggle of printed news to avoid obsolescence, papers around the turn of the twentieth century enjoyed widespread popularity. National circulation of dailies rose by seventy-eight percent in the 1880 s, and by the late 1920s Stanford University professor Eliot Grinnell Mears found Americans to be "great readers of newspapers and popular periodicals" who "believe most of what they read." ${ }^{11}$ Oregon followed the national trend, according to British sojourner Wallis Nash and journalism professor George S. Turnbull. The latter attests that "to the limit of their resources, in money and talent the Oregon papers, from the beginning, have reflected the community," while Astorian papers and editors "rather consistently enjoyed a high standing" into the 1930s. ${ }^{12}$

Local editors further demonstrate the high public regard of Astoria's two main newspapers, the Astorian and the Budget. DeWitt Clinton Ireland was an East Coast publishing veteran who migrated to Oregon in 1861, founding the Oregon City Enterprise before moving to Astoria. He started the Astorian in 1873 and began

\footnotetext{
${ }^{10}$ Kevin G. Barnhurst and John Nerone, The Form Of News: A History (New York, 2001), 187 and 142. I am treating the newspapers in Astoria as a combination of Barnhurst and Nerone's "Victorian" and "Industrial" papers, since they have some qualities of each.

${ }^{11}$ Eliot Grinnell Mears, Resident Orientals on the American Pacific Coast (reprint; Chicago, 1978), 389.

${ }^{12}$ George S. Turnbull, History of Oregon Newspapers (Portland, Ore., 1939), 313 and 310; also Wallis Nash, Two Years in Oregon (New York, 1882), 214 - 215.
} 
printing anti-Chinese material about once a week. ${ }^{13}$ Astoria's white population meanwhile voted Ireland into the mayor's office in both 1876 and $1880 .{ }^{14}$ Details are scant and conflicting regarding the management of the paper in the following twenty years, but Ireland sold the Astorian to John F. Halloran and Pitman W. Parker in 1880. ${ }^{15}$ John Dellinger, another experienced newspaperman, took over the paper in 1903 and operated it until his death in 1930.

Ireland's rival Oscar Dunbar co-founded the Budget in 1892 or 1893 with John Gratke and also enjoyed public favor locally. When his pointed editorials landed him in jail for libel in the early 1890s, hundreds of citizens petitioned for his release, and when it was granted they greeted Dunbar with a brass band and paraded him through the city with his family. ${ }^{16}$ Mass demonstrations of support such as this and Ireland's successful campaigns imply a link between the major local newspapers and the pulse of the town, making the papers a useful tool in discussing local attitudes toward the Chinese.

\footnotetext{
${ }^{13}$ Liisa Penner, introduction to The Chinese in Astoria, Oregon, 1870 - 1880 (Astoria, Ore., 1990). Penner found about two hundred Chinese references in Ireland's papers between 1873 and 1880, in a survey that scanned about 40 percent of the issues. This is even more significant when you take into account the fact that his paper ran tri-weekly, and not daily, for the first three years, and was also weekly for a year in 1876 - 1877.

${ }^{14}$ Ibid.; Roger T. Tetlow, The Astorian_(Portland, Ore., 1975) 126 and 130. According to Tetlow, both elections were won by wide margins, although the book is a blend of fact and fiction and does not cite any sources to support those claims.

15 Turnbull, History of Oregon Newspapers, 304; East Oregonian Publishing Company, "The Daily Astorian," http://www.eopubco.com/papers/da_hist.html; The Daily Astorian, "About," http://www.dailyastorian.com/site/about/. Turnbull claims that Dellinger purchased the Astorian from "Lyle and Patterson" rather than Halloran and Parker in 1903, though he refrains from further details regarding who Lyle and Patterson are or how they acquired the paper. The East Oregonian Publishing Company, which now owns the Astorian, states contrarily on its website that Halloran and Parker did sell the paper to Dellinger, while the Astorian's own website simply omits any owners' names between Ireland and Dellinger.
} 
Even more directly involved in the lives of Chinese were immigration officials, and chapter two focuses on those officials who handled Chinese cases. The impact of the immigration administration on Chinese already in the United States is easy to overlook, but its combination of racially-charged international and domestic affairs played a significant role in the lives of immigrants even after immigration took place, thanks in large part to the legal strictures aimed at Chinese during these years.

Chinese immigrants in the United States faced unprecedented legislative obstacles beginning in the late nineteenth century that played out in Astoria's immigration office. The 1862 Anti-Coolie Law and the 1875 Page Law targeted Chinese slaves and prostitutes, but neither had as sweeping an impact as the exclusion acts passed between 1882 and 1904 that explicitly denied the immigration of all Chinese who did not fit into certain non-laboring categories. ${ }^{17}$ The initial Chinese Exclusion Act, as Erika Lee has remarked, changed the United States into "a new type of nation," one defined by immigration gatekeeping. ${ }^{18}$ Historian Najia Aarim-Heriot asserts that the Exclusion Act functioned as the "hinge on which all subsequent American immigration policy turned and the foundation of American immigration law"; the exclusion paradigm stayed in effect until $1943 .{ }^{19}$ The act was originally

\footnotetext{
${ }^{16}$ Turnbull, History of Oregon Newspapers, 307 - 309.

${ }^{17}$ Chinese exempt from exclusion included merchants, teachers, students, government officials, and tourists. Laborers already in the United States could also leave and return, provided they obtained proper documentation.

${ }^{18}$ Erika Lee, At America's Gates: Chinese Immigration During the Exclusion Era, 1882 - 1943 (Chapel Hill, N.C., 2005), 6.

${ }^{19}$ Najia Aarim-Heriot, Chinese Immigrants, African Americans, and Racial Anxiety in the United States, 1848 - 82 (Urbana, Ill., 2003), xi.
} 
designed as a ten-year measure, but was extended for another decade by the 1892

Geary Act, the latter being "the most draconian immigration law ever passed,"

according to historian Sucheng Chan ${ }^{20}$ Congress added ten years again in 1902, and

then passed a permanent extension in 1904. Various other acts, such as the $1888 \mathrm{Scott}$

Act and 1891 Immigration Act, also served to tighten the restrictions on immigration

eligibility and complicate the travel requirements for Chinese already in the United

States. The Immigration Act of 1924, where this study ends, instituted national-

origins-based quotas for the first time, brought Chinese exclusion to its pinnacle, and

extended exclusion policy to include Asians in general. ${ }^{21}$

While policy changes made the immigration process progressively stricter

between 1882 and 1924, shifts in administrative structure forced continual change in

the immigration office. The chain of command above the local immigration office

reorganized at least six times between 1891 and 1913, and these reorganizations in

addition to policy changes every few years kept officials constantly adjusting to their

jobs. ${ }^{22}$ Astoria's location on the West Coast added to the difficulty of keeping up with

\footnotetext{
${ }^{20}$ Sucheng Chan, ed., Entry Denied: Exclusion and the Chinese Community in America, 1882 - 1943 (Philadelphia, 1991), 18.

${ }^{21}$ For a more thorough consideration of the Immigration Act of 1924, see Mae M. Ngai, "The Architecture of Race in American Immigration Law: A Reexamination of the Immigration Act of 1924," The Journal of American History 86, no.1 (1999): 67 - 92.

${ }^{22}$ Estelle Lau, Paper Families: Identity, Immigration Administration, and Chinese Exclusion (Durham, N.C., 2006), 18 - 20 and 103 - 104; Marie Rose Wong, Sweet Cakes, Long Journey: The Chinatowns of Portland, Oregon (Seattle, 2004) 76 - 78. The Treasury Department's Customs Service handled immigration before 1900. The Office of the Superintendant of Immigration formed in 1891 and became the Bureau of Immigration in 1895, assuming exclusion duties apart from the Customs Service in 1900. Chinese exclusion administration was finally consolidated with general immigration in 1903, when the Bureau moved to the Department of Commerce and Labor, then the Department of Labor in 1913. Meanwhile, the Bureau changed into the Bureau of Immigration and Naturalization in 1906, and split
} 
mandates from Washington, D.C. Consequently, local inspectors maintained a large amount of discretion in their implementation of policy. ${ }^{23}$

Despite changes in the law and administration, one constant was the importance of merchant status for Chinese. Chapter three examines Chinese business partnerships in Astoria, for two reasons: first, to show that they were there, since this history has not been extensively documented; and second, to look at their relationship to the white population, paying special attention to the Immigration Bureau's treatment of different merchants and firms. Astoria's Chinese merchants took part in an extensive international economic network with a long history, and despite the strength of their overseas entrepreneurship overall, Chinese immigrants during this time period were commonly addressed as a population of laborers, and still today there is little writing devoted to Astoria's merchants. ${ }^{24}$ Historian Marie Rose Wong, for example, has asserted that "a Chinatown and its merchant-based support system for supplying Chinese goods and services never took firm hold in Astoria." ${ }^{25}$ While it is true that Astoria did not sustain a number of Chinese merchants comparable to Portland and San Francisco, it was not the case that there were no business networks

to make the Bureau of Immigration and Bureau of Naturalization in 1913. For simplicity's sake, and because the Astoria personnel did not usually change along with the organizational structure, I will make general references to the government's administrators of immigration policy in the following pages, rather than specifying the exact agency names and titles.

${ }^{23}$ An example of the Astoria office lagging behind changes made in Washington can be found in "Wong Gum Yuen," Case File 2102, Box 9, Portland District Office, Chinese Exclusion Acts Case Files, 1891 - 1943, Records of the Immigration and Naturalization Service, Record Group 85, National Archives and Records Administration-Pacific Region (Seattle).

${ }^{24}$ For several references to the earlier history of overseas Chinese economic activity between 1400 and 1800, see Andre Gunder Frank, ReORIENT: Global Economy in the Asian Age (Berkeley, 1998), 62 63, 102 - 104, 113 - 114, 180 - 181, and 218 - 219. 
in Astoria. As Chris Friday has shown, local Chinese merchants increased numerically between 1880 and 1910, and immigration records indicate that Chinese business networks maintained a significant presence and enjoyed financial success in Astoria into the 1920 s. $^{26}$

Merchant status was central to immigration matters. Under the exclusion acts, laborers were not legally allowed to enter the United States, and, moreover, those regarded as "good" merchants typically drew less suspicion in immigration matters. Local inspectors formed opinions about different companies and treated their merchants accordingly, and on this basis we can draw out three implicit categories of Chinese firms before the immigration office: those in good standing, those in poor standing, and the ambiguous firms in the middle. Merchants of respected firms tended to have fewer application complications with amiable, short interrogations and favorable comments from the inspectors. Members from suspect firms tended to have more denied applications and more suspicious incidents than those from respected firms, though some still had high success rates in the immigration office. Ambiguous firms were a blend of the first two types, so in these cases the inspectors could not use individuals' company affiliation as a helpful indicator of how to proceed. These divisions related strongly to respective firms' known attempts to support false merchants, as well as their status in the local business community.

Though they approached the task differently, newspapers and immigration

\footnotetext{
${ }^{25}$ Wong, Sweet Cakes, 156.
} 
records were both concerned with delineating "good" and "bad" Chinese immigrants, and both reveal a class bias that favored merchants over laborers. This class bias came with vilification of the Chinese "horde" in the news, as well as movements to expel Chinese workers from the canning and laundry industries. It also dictated the inspectors' search for laborers claiming to be merchants. The other side to this bias is that the Chinese merchant class gained social acceptance and respect among Astoria's white elite that carried over into the immigration office, where merchants regarded as genuine faced less severe treatment. Chinese merchants, the "good" Chinese, took advantage of this bias to succeed socially and economically in the early twentieth century despite continued anti-Chinese sentiments and exclusion laws.

${ }^{26}$ Friday, Organizing Asian American Labor, 72 - 75 and 197. 
Chapter Two - Newspapers and the Chinese

In the fall of 1902, reports of a bear sighting threatened Smith Point residents on the outskirts of Astoria, Oregon. The Morning Astorian warned that the animal visited populated areas every day, but made light of the issue by describing the bear as unarmed and little more than a threat to the "radishes and cabbages" of a nearby Chinese-owned garden. Moreover, a posse of eight non-Chinese men had formed to dispose of the matter; President Roosevelt, the report continued, expressed disappointment that he would miss the hunt. The paper even published a short chronology of the posse's first day of activity. In the end, the pursuit proved fruitless, the most notable event being the unexplained disrobing of a couple of children, bringing them "near the bare." The day concluded with the animal "making lettuce salad in the Chinaman's kitchen." 1

Interloping bears make for important news, of course, but here the story's expression is of greater importance than the event itself, as it exemplifies the popular turn-of-the-century ambivalence toward Chinese in Astoria. The reader is left to decide what constitute the actual merits of pursuing the bear, and why the gardener never makes an appearance during the entire episode. These questions, in turn, rest on another unclear point: whether or not the garden owner is an ally. The posse may very well be out to help the Chinese as part of the community, but the way the bear is made

\footnotetext{
${ }^{1}$ Morning Astorian, "Big Bear at Smith's Point," Sept. 2, 1902, p. 3.
} 
to seem at home in the Chinese dwelling suggests an affiliation between the two, and even conflates the two in an implicit way. There is a similar ambiguity in the overall body of accounts about Chinese residents in Astoria during the years between 1882 and 1924.

A historical perspective makes sense of this in a trajectory over time. What emerges from local press is the importance to white Astorians of class among Chinese immigrants, specifically the distinction between merchants and laborers. Relations with the white community changed over time as the local Chinese population evolved. ${ }^{2}$ Most of the negative stereotypes associated with Chinese in the 1870 s and 1880s were associated with the laboring class. Consequently, as the local Chinese demographic shifted toward a core of merchants, hostility decreased. Through the 1880s and early 1890s, newspaper accounts maintained an unequivocally anti-Chinese position, calling repeatedly for the expulsion of local Chinese and denigrating their presence. However, as Chris Friday has observed, after the canning boom peak in the mid-1880s Astoria's Chinese population steadily declined, even though the city's population otherwise grew. ${ }^{3}$ Simultaneously, anti-Chinese news accounts diminished on a similar curve after the 1880 s. Some open hostility lingered in the media for a decade or so, but by 1905 the Astoria Daily Budget had turned to concern over

\footnotetext{
${ }^{2}$ See Philip P. Choy, Lorraine Dong, and Marlon K. Hom, Coming Man: 19th Century American Perceptions of the Chinese (Seattle, 1995), 21.

${ }^{3}$ Chris Friday, Organizing Asian American Labor: The Pacific Coast Canned-Salmon Industry, 1870 1942 (Philadelphia, 1994), 58 - 59.
} 
Japanese migrants. ${ }^{4}$ By the latter year, what was perceived as a receding Chinese threat seemed benign enough to have fun with, particularly by mocking pronunciation and sensationalizing traditions. Customs such as human bone deportations, patterns of dress, and celebrations evoked condescending but amused expressions of tolerance from the white media. The Chinese New Year festival, for instance, involved deafening, prolonged firework lighting that disturbed the evening of many nonChinese in the vicinity for multiple days annually. For example, Astoria's Chinese community partied for ten straight days in the early 1900 s. $^{5}$ Yet no major conflicts erupted, and the city passed no restrictive laws regarding this sonorous assertion of the Chinese presence. Later accounts closer to 1920 suggest an even greater acceptance of and respect for the Chinese merchant class.

The centrality of Chinese to Astoria's economy partially explains the white community's willingness to endure such a large Chinese presence in the 1880s and 1890s. The all-important salmon canning industry depended on Chinese labor over the last two-and-a-half decades of the nineteenth century. As Chris Friday notes, "After 1873 , the canneries grew in direct proportion to the availability of Chinese." ${ }^{6}$ Chinese remained essential to the industry into the twentieth century. In fact, during World War One some Astorians campaigned for a break from exclusion policy. Mayor Francis Harley traveled to Washington D.C. in 1918 to promote an amendment

\footnotetext{
4 "Foreigners Coming," Astoria Daily Budget, June 9, 1905, p. 2.

5 "Bond Street," Daily Astorian, April 26, 1973, p. 8B.

${ }^{6}$ Friday, Organizing Asian American Labor, 26.
} 
admitting Chinese worker-immigrants in the interest of boosting wartime production. ${ }^{7}$ Laundry work also constituted a sphere of Chinese influence, where they held a monopoly until the first white-operated laundry opened in 1891. Moreover, white households in the area extensively employed Chinese cooks and servants. Traveler Wallis Nash attested in 1882 that "on this coast they are simply indispensable" as domestic help, and Alex Normand, of nearby Olney, remembered Chinese servants in almost every house in the $1880 \mathrm{~s}^{8}$ In short, it seems that the Chinese labor contributions were widespread enough to trump racial hostility and justify a tolerance of their presence among significant numbers of the white population.

While Chinese laborers performed work important to the local European American population, their concentration in canning, cooking, and other manual labor also lessened competition with white job seekers. The result was an example of the dual labor system that Richard White has postulated as a region-wide phenomenon, where white workers largely occupied the higher-paying and skilled positions, leaving the most menial and lowest-paying jobs to the nonwhite workforce. ${ }^{9}$ Historian Alexander Saxton has argued that this situation was a boon to skilled white labor unionists, who were able to avoid competition from most nonwhites and manipulate

\footnotetext{
7 "City's Mayor Back of Scheme to Throw Down Bars to Cheap China Labor," Morning Astorian, Aug. 29, 1918, p. 1. The proposed amendment failed.

${ }^{8}$ Wallis Nash, Two Years in Oregon (New York, 1882), 205; Emma Gene Miller, Clatsop County, Oregon: Its History, Legends, and Industries (Portland, Ore., 1958), 199.

${ }^{9}$ Richard White, "It's Your Misfortune and None of My Own": A New History of the American West (Norman, Okla., 1993), 282 - 284; ---, "Race Relations in the American West," American Quarterly 38 (1986), 409. Chinese in the canning industry also took the foreman and contractor jobs, but there was a much greater number of laborers.
} 
the Chinese presence for political power. ${ }^{10}$ Chinese labor could also be exploited for its productivity without disrupting patterns of subordination and white economic opportunities. However, the way white workers politically leveraged Chinese labor was by agitating against it socially, and there were also a sizeable number of workingclass whites in Astoria who competed with the Chinese for jobs, especially during the economic depression of the 1890s. In this context, the structure of the Chinese labor force could both favor the white population in certain ways and pose a perceived socioeconomic threat in others.

The racially-charged antipathy around Astoria's economic situation was pronounced but did not manifest in riots or an actual expulsion of Chinese workers. Generally in the late nineteenth century West a threefold anti-Chinese labor argument held that the Asians were not only unsanitary, but also displaced white workers and thereby lowered white living standards. A local example of this trend can be seen in the laundry business. Though it conceded that some whites did take their clothes to Chinese washers, the Daily Astorian heralded the first local white-owned laundromat in 1891 as "an opportunity for white people to patronize a worthy enterprise" in a denunciation of Chinese "disgusting practices." 11 The Astoria Daily Budget echoed these sentiments in an 1894 editorial complaining that "they almost ruined the laundry, the shoe making, cigar making, tailoring, and in fact nearly every other kind

\footnotetext{
${ }^{10}$ Alexander Saxton, The Indispensible Enemy: Labor and the Anti-Chinese Movement in California (Berkeley, 1971), 263 - 265.

11 "Who Does Your Washing?" Daily Morning Astorian, April 1, 1891.
} 
of business." ${ }^{12}$ These views reflected those of labor advocates in major Pacific markets, who vehemently supported Chinese exclusion, and such feelings lingered into the twentieth century in Astoria, though becoming less pronounced. While the Morning Astorian still favored exclusion because excessive cheap labor made conditions "impossible for white workers to exist," the mayor's campaign for a temporary reprieve in Chinese exclusion laws during wartime made the debate less one-sided. ${ }^{13}$ As the 1920 s approached, tension remained over the presence of Chinese laborers, but the sinking local Chinese population deflated the relevance of the matter. Agitation over a Chinese workforce only made sense when their numbers were increasing.

The climax of white labor groups' anti-Chinese activities was the drive to physically expel Chinese, which percolated through the West and peaked between 1885 and 1887. Twenty-eight Chinese were murdered in Rock Springs, Wyoming in 1885, and a number of incidents occurred in the following weeks in Oregon, Washington, and Idaho, especially around Seattle, Tacoma, and Portland. Expulsionrelated violence continued in the Seattle area into 1886 . The most deadly anti-Chinese massacre of the era occurred in 1887 in Hells Canyon, when thirty-one Chinese miners were killed by a gang of outlaws. ${ }^{14}$

The Chinese expulsion movement did reach Astoria, but with little effect,

\footnotetext{
${ }^{12}$ Astoria Daily Budget, Sept. 15, 1894.

13 "City's Mayor," Morning Astorian, Aug. 29, 1918.

${ }^{14}$ Roger Daniels, Asian America: Chinese and Japanese in the United States since 1850 (Seattle, 1988), 59 - 64.
} 
coming to a head early in 1886 when the Knights of Labor persuaded several cannery owners to pledge an end to Chinese employment by autumn. ${ }^{15}$ Given that the local canning industry was still at its peak, nothing came of the agreement and no violence á la Tacoma erupted. However, it is telling that when the Portland Oregonian hinted at imminent race riots in Astoria during the same month, the Weekly Astorian condemned Portland's meddlesome ways but avoided an actual denial of the interracial friction. ${ }^{16}$ The editors promoted good race relations not as a goal in itself but as a means to maintain civility and social order.

Hostility toward Chinese in the 1880 s was both common and direct in Astoria's news reports. A lengthy Saturday editorial in the 1886 Weekly Astorian entitled "Free Versus Slave" exemplifies this antagonism and underlines its economic nature. Promoting a proposed total exclusion bill in the U.S. Senate, the author characterized Chinese immigrants as slaves who debased the United States by their very presence. This "defilement of this fair land by a heathen horde" had more than one component to it, but at the center was a perceived transactional inequity, the idea that "there is no reciprocity at all in our dealings with China" in terms of immigration and economic privileges. This point is returned to several times, and the writer made it clear that only a total end to Chinese immigration would solve the issue, for "there are millions of them standing ready to overwhelm us if the gates are not finally and firmly shut." By taking care of its economic interests in this way, America would

\footnotetext{
15 "An Important Measure," Weekly Astorian, Feb. 27, 1886.
} 
relieve multiple problems at once and complete a hyperbolically-construed "social, moral, industrial, hygienic, financial and ethnological revolution." The author admitted to knowing very little about the Chinese as people, but asserted that economic measures would bestow cultural benefits. ${ }^{17}$

Part of the significance of the "Chinese question" was that it offered an important point of agreement for many western whites, without Civil War baggage. Like blacks in the South, the West's Chinese stood as a highly visible minority, both coveted and resented for their important role in the economy by many local whites. Alexander Saxton has asserted that, in this way, southern blacks and western Chinese experienced similar social climates, stating that "Chinese fitted easily enough into that mental compartment which in the East had been reserved for blacks." ${ }^{18}$ The matter may not have been strictly as simple as this sounds, but it is true that Astoria's newspapermen also made the connection. "Free Versus Slave" estimated that Chinese exclusion promised to "rank second in the great moral and philanthropic movements of the epoch" behind the abolition of black slavery. ${ }^{19}$ This allowed for the continued survival of antebellum economic and ideological paradigms and helped to keep racial

\footnotetext{
16 "Excess of Kindness," Weekly Astorian, Feb. 20, 1886, p. 3.

17 "Free Versus Slave," Weekly Astorian, Feb. 27, 1886.

${ }^{18}$ Alexander Saxton, The Indispensable Enemy: Labor and the Anti-Chinese Movement in California (Berkeley, 1971), 260.

19 "Free Versus Slave," Weekly Astorian, February 27, 1886; US Immigration Legislation Online, "1862 Anti-Coolie Law," http://library.uwb.edu/guides/USimmigration/1862_anti_coolie_law.html; Saxton, Indispensible Enemy, 76 - 77. The author of "Free Versus Slave" echoed concerns about "coolieism" that had led to an anti-coolie act in 1862, along with the Central Pacific Anti-Coolie Association in San Francisco that began in the late 1860s.
} 
ideas linked to economic scenarios in the American West. ${ }^{20}$

Aside from their role as a second-tier labor force, Astoria's Chinese generally experienced a social segregation that resembled the black experience in other parts of the country. This occurred particularly in settlement patterns. In specific city blocks and lodging adjacent to the canneries, Chinese were almost completely segregated. ${ }^{21}$ Even before 1880, the Weekly Astorian worried over whites' ability to "colonize the Chinese in any one place in the city," advising that "it should be done if possible," and insurance maps continued to mark out Chinese-occupied buildings into the next century. ${ }^{22}$ We should not discount the likelihood that many Chinese actually wanted to live close to their compatriots, but in any case the white community favored racially segregated neighborhoods. Astoria's public schools did accept Chinese students, unlike San Francisco's schools, but Chinese children were few before the twentieth century, when merchant families increased. ${ }^{23}$

Various municipal laws aimed at the Chinese strongly suggested the contemporary South, too. Like Jim Crow, Astoria's legal system targeted Chinese with restrictive measures of control. The city passed a cubic air ordinance in 1886 to regulate Chinese living quarters, and the city council debated legislation to prevent Chinese burials in the local cemetery (though council members would know, if they

\footnotetext{
${ }^{20}$ Ibid., 261.

${ }^{21}$ Friday, Organizing Asian American Labor, 57.

${ }^{22}$ Ibid.; Weekly Astorian, May 23, 1879; Sanborn Map Co., "Astoria, OR," (Sanborn, 1908), Clatsop County Historical Society.

${ }^{23}$ Joyce Kuo, "Excluded, Segregated, and Forgotten: A Historical View of the Discrimination Against Chinese Americans in Public Schools" Chinese America: History and Perspectives (2000), 32 - 48.
} 
read the papers, that Chinese did not need permanent cemetery plots, as their bones were periodically sent to China). ${ }^{24}$ Municipal government even took aim at productive activities, such as when it banned Chinese farmers in 1910 from keeping pigs within the city limits. The pigs were deemed a public health nuisance by petitioners, but this was only ostensibly reasonable, as the swineherds disposed of Astoria's kitchen garbage in the absence of a municipal service. ${ }^{25}$ An additional fiat against toting items with poles, as the Chinese often did, resulted in multiple arrests, according to one historian. $^{26}$

A less openly malicious black-Chinese similarity was the white caricature of each groups' speech. Although Astoria never housed a large black population, white attitudes emerge in a 1919 ad featuring the broken English of cartoon figures "Sergeant Black" and "Private Blacker." ${ }^{27}$ Likewise, white writers seemed to derive amusement from what they perceived to be the Chinese English dialect. One news report about a police gambling raid, for instance, concludes: "Lee stood, crestfallen and disconsolate, in the midst of the wreck and told a visitor he was through, this time

\footnotetext{
${ }^{24}$ Weekly Astorian, Feb. 27, 1886. See Nayan Shah, Contagious Divides: Epidemics and Race in San Francisco's Chinatown (Berkeley, 2001); also Marie Rose Wong, Sweet Cakes, Long Journey: The Chinatowns of Portland, Oregon (Seattle, 2004) 38 - 39. Cubic air ordinances originated in San Francisco as an unsuccessful effort to prevent overcrowding in Chinese residences. A building's volume, or "cubic air capacity," was used to determine the number of inhabitants legally allowed in the building. Regarding burial limitations, see "City Council Proceedings," Weekly Astorian, June 19, 1886. Chinese bone shipments across the Pacific were frequently mentioned in Astoria's papers; see Daily Morning Astorian, Sept. 28, 1888 and "Chinese To Be Exhumed," Daily Morning_Astorian, June 10, 1891.

${ }^{25}$ Astoria Daily Budget, Feb. 2, 1910, p.6 col. 2.

${ }^{26}$ Miller, Clatsop County, 198.

${ }^{27}$ Morning Astorian, Oct. 4, 1919.
} 
'forlebber."' ${ }^{28}$ Newspaper accounts frequently featured this type of language when dealing with Chinese, showing a nascent measure of tolerance with their apparent attempts at humor. A funny Chinaman was not necessarily an equal, but could be lived with nonetheless. This attitude may have been helped by the fact that in the years around World War One, when the two above articles appeared, Astoria's black and Chinese populations were both small. ${ }^{29}$

Borrowing paradigms from interactions with African Americans was just one way to racially categorize Chinese to whites' advantage. ${ }^{30}$ In Authentic Indians, Paige Raibmon describes racial contact between whites and Native Americans in terms of social binaries that the white population imposed on other groups, and these binaries construed a host of characteristics in terms of strict opposites with no middle ground. ${ }^{31}$ While Raibmon does not address Chinese, her point—-showing how the dominant white society reinforced hierarchical difference from other "races" by its lexicon-is valid and the lense of social binaries is helpful for other race relations in the region as well. Astoria's Chinese were differentiated from whites in a similarly

\footnotetext{
28 "Notorious Gambling Place of Charley Lee Now Is Total Wreck," Morning Astorian, Sept. 10, 1918, p. 1.

${ }^{29}$ Clatsop County census, Oregon, Fourteenth Census of the United States, Washington, D.C., Bureau of the Census, 1920, Microfilm, Oregon Historical Society collections. I counted 204 Chinese in the county census for 1920. The African American population was never substantial in Astoria between 1882 and 1924.

${ }^{30}$ Instances of connecting the black and Chinese experiences in the United States are found in Alexander Saxton, The Indispensible Enemy, 2 and 260 - 261; John R. Wunder, "The Chinese and the Courts in the Pacific Northwest: Justice Denied?" The Pacific Historical Review 52, no. 2 (1983): 206; and Najia Aarim-Heriot, Chinese Immigrants, African Americans, and Racial Anxiety in the United States, 1848 - 82, (Urbana, Ill., 2003), 8 - 13 and 37 - 38.

${ }^{31}$ Paige Raibmon, Authentic Indians: Episodes of Encounter From the Late-Nineteenth Century Northwest Coast (Durham, N.C., 2005), 3 - 14.
} 
dichotomous fashion, and using some of Raibmon's dichotomies illustrates this while also subtly emphasizing the importance of class among Chinese immigrants.

One characteristic portrayal of Chinese was as slightly less than human, a theme easier to apply to large crowds of faceless laborers than to specific merchants whose business dealings involved personal interactions. Consider again the bear hunt, in particular, the bear's alleged use of the Chinese resident's cooking facilities: this was an apparent stab at humor, but it also expressed the idea of Chinese affinity with animals. American political cartoons affirmed this notion often, drawing Chinese as monkeys, rats and dragons; one even showed them evolving into pigs. ${ }^{32}$ Astoria's papers tended to avoid such imagery, but they did participate in the rhetoric. Thus local Chinese spoke "pigeon" English, wore "pig-tails," and gathered "as black ants around a sugar barrel," and their music sounded to white ears like a tomcat's wail. ${ }^{33}$ Though not always explicitly inimical, these animalistic descriptions encouraged a separation of the nature-bound, uncivilized Chinese from civilized white society. This separation became more difficult as the Chinese demographics evolved, as suggested by this exchange during the investigation of the merchant Lum Ah Quinn, who also went by China Joe:

"'Does China Joe talk plain English?'

'He talks good English.'

'Good English?'

'Fairly good for a Chinaman.'

\footnotetext{
${ }^{32}$ Choy et al., Coming Man, 102 and 111.

${ }^{33}$ Daily Morning Astorian, Nov. 21, 1891; Astoria Daily Budget, Sept. 14, 1894; "A Chinese Funeral," Weekly Astorian, June 19, 1886.
} 
'Talks pigeon English?'

'He talks fairly good English.'

'What do you mean?'

'The average man can understand him.'

'That is a man who understands Chinamen?'

'Yes.'

'He would have to be a man who understands Chinamen and have a fair knowledge of pigeon English?'

'I would call it fairly good English."'34

Although the witness is reluctant to elaborate, he refuses to state that Lum speaks

"pigeon English." Whatever the specific reasons for this, it is symptomatic of Chinese

merchants' more equal relations with the white community than those of laborers.

With their superior English proficiency and better-established connections to the

white community, the merchant class was harder to coherently affiliate with animals.

Subhuman characteristics were a specific instance of a broader dichotomy, one that distinguished between dominant and subordinate groups. More than half of Astoria's Chinese were cannery workers until at least 1910, reinforcing the natural appearance of these categories. According to the Weekly Astorian, the local movement to expel the Chinese was a mistake, but only because there were no white laborers available as replacements so late in the season. ${ }^{35}$ Other news accounts similarly assumed Chinese subservience throughout the period in question. During World War One the Morning Astorian expressed its views in a front-page article

34 "Lam Quinn," Case File 5001/9, Box 50, Portland District Office, Chinese Exclusion Acts Case Files, 1891 - 1943, Records of the Immigration and Naturalization Service, Record Group 85, National Archives and Records Administration-Pacific Region (Seattle) (Hereafter cited as RG 85, NA).

${ }^{35}$ Weekly Astorian, Feb. 20, 1886, p. 3 col. 4. 
entitled, "Chinese Welded Into Integral Part of Army." ${ }^{36}$ Notably, the newspaper renders the "Chinese" as a passive object and not an active subject. More importantly, the piece boiled down the Chinese war contribution to manual labor, assuming that this is the proper Chinese role. The conclusion goes on to extol the progressive influence these workers would have upon returning to China, since the Army had educated them and taught them to be so productive.

Merchants were less susceptible to subordination in news accounts. The Astorian's 1894 advertisement for Wing Lee's business suggests his inclusion in the community, and later accounts show an even deeper integration of the Chinese business class by social and economic participation. ${ }^{37}$ When Chinese merchants added decorations for the city's centennial celebration in 1911, the Budget noted the act and commended their "enterprise and public spirit." In 1913 at least eleven individual Chinese merchants and three firms contributed to the Y.M.C.A. building fund, an act that made a first page headline. Such civic activity shows that the merchants invested in the community on a basis of some equality, an equality confirmed by the white citizens and media. $^{38}$

Feeding off of the more basic hierarchical dichotomies was a cluster of related cultural binaries that pitted modern against traditional, native against foreign, and Christian against pagan, all of which emphasized Chinese foreignness. Astorian

\footnotetext{
36 "Chinese Welded into Integral Part of Army," Morning Astorian, Sept. 4, 1918.

${ }^{37}$ Daily Astorian, Feb. 6, 1894 and Feb. 7, 1894.
} 
papers' portrayals of Chinese customs and habits often commented on how strange and pagan it was for them to exhume compatriots' bones and send them to China, for instance. ${ }^{39}$ A brief, desultory passage from 1891 attested that Chinese assigned numbers, not names, to baby girls, since they only cared about male offspring. ${ }^{40}$ Merchants, for their part, transcended some cultural differences by their economic and social characteristics. Their wealth commanded some cross-cultural respect, and trading with white businesses, as did the grocer Lum Quing with I.F. Morrison, automatically imparted a level of parity. ${ }^{41}$ Moreover, Chinese businessmen adapted more readily to the social norms of the surrounding society, in large part because they more frequently started families than did the laborers. This made the merchants appear more "normal," and children also connected parents to white society by attending public schools and church Sunday schools. ${ }^{42}$ The merchants' resulting visibility and ability to accumulate reputations with white locals helped them to partly escape cultural bias.

Business dealings, family connections, and familiarity similarly distanced

\footnotetext{
${ }^{38}$ Astoria Daily Budget, Aug. 14, 1911, p. 6; "Liberality of Chinese Boosts Fund," Astoria Daily Budget, Nov. 25, 1913, p. 1. The editor exaggerates with his compliments in the 1911 article, and this may be sarcasm, but still it comes across as a rather positive depiction of the Chinese.

${ }^{39}$ Daily Morning Astorian, Sept. 28, 1888; "Chinese To Be Exhumed," Daily Morning Astorian, June 10, 1891. Astoria's papers frequently remarked upon the immigrants' practice of sending bones to China.

${ }^{40}$ Daily Morning Astorian, Nov. 21, 1891.

41 "Lum Quing," Case File 2135, Box 9, RG 85, NA

42 "Seid Yuen," Case File 1810, Box 5, RG 85, NA.; "Gem Lung," Case File 4273, Box 31, RG 85, NA. There is some evidence of efforts to proselytize the immigrant population by some local congregations, and while church attendance among the Chinese does not seem to have been particularly high, it was remarked upon favorably in some immigration cases and probably played a propitious role in the reputations of certain Chinese.
} 
Chinese merchants from a fourth pair of opposite categories, "individual" and "collective," ideas reinforced by speaking of Chinese as groups of nameless people. Occasional Chinese names made their way into news stories before the turn of the century, but usually this occurred in relation to death, crime, violence, or a combination. ${ }^{43}$ Often, the press favored the anonymous moniker of "John Chinaman," usually condensed simply to "Chinaman." Frequently, too, Chinaman became Chinamen. When not swarming like ants, "newsworthy" Chinese flocked to the country, clustered in secret, and congregated to celebrate old and illogical traditions. So, regardless of what newspaper writers actually believed, they advertised the Chinese as an inherent threat. Once planted, the idea had a chance to thrive on Chinese reservedness; one local, John Lum, recalled that the desire to make a living, along with white rejection, prompted the Chinese to generally stay aloof. ${ }^{44}$ Chinese social organizations, largely mysterious to the white population, gave additional backing to the impression of Chinese as a separate, cohesive mass. The individual white reader never knew what the Chinamen, numerous, anonymous, and unintelligible, might do.

Association with vice, filth, and violence also made Chinese appear more threatening, and all three typified news accounts of Chinatown in Astoria, especially before the turn of the century. This served to promote racial stereotypes, but

\footnotetext{
${ }^{43}$ For examples referring to death, crime, and violence, see Daily Morning Astorian, Dec. 7, 1888, p. 3 col. 1 and Astoria Daily Budget, Sept. 17, 1900, p. 4 col. 1 and 2 (two reports). Of the articles referring to Chinese that I sampled prior to 1900, 22 percent mentioned specific Chinese names; those after 1900 named Chinese individuals 54 percent of the time.
} 
sometimes came with condoning undertones, perhaps due to the white population's own involvement in these activities. ${ }^{45}$ However, none of these things significantly damaged the standing of Chinese merchants in the community.

Astoria's police and media paid much attention to Chinese gambling houses in the 1910s as authorities cracked down on such establishments. City cops conducted at least ten raids in two months of 1918 alone. ${ }^{46}$ This served to shape the public image of Chinese, but neither police nor newspapers were entirely condemning of the industry. Although some gambling joints, like that of Lum Gut, were eventually demolished, most cases evidently ended in arrests and immediate releases on bail, suggesting a "prosperous and increasing business" between the police department and the gamblers, or at least a relationship of some mutual benefit. ${ }^{47}$ Meanwhile, newspapers increased coverage of Chinese gambling in the 1910s but showed more concern over authorities' apparent profit from the industry than with the gambling itself. The 1902 Daily Astorian viewed Chinese lotteries as so benign that they were exempt from "all the evil effects attributed to other methods of 'taking a chance."'48

Along with vice industries came concerns over disease and poor sanitation in

\footnotetext{
44 "Bond Street Chinatown Close Knit Community," Daily Astorian, April 26, 1973, p. 8B.

${ }^{45}$ Field report of Agent Bryon, Sept. 12, 1918, Case 8000 - 71351, Old German Files, 1909 - 1921, Investigative Reports of the Bureau of Investigation, 1908 - 1922, publication number M1085, http://www.footnote.com/image/\#488446. According to this federal report, Astoria's mayor, Francis Harley, controlled extensive "underworld" operations.

46 "Nine Taken in Lottery Game Raid," Morning Astorian, Aug. 28, 1918, p. 1; "Charley Lee," Morning Astorian, Sept. 10, 1918, p. 1.

${ }^{47}$ Astoria Daily Budget, March 31, 1904, p. 4 col. 3. Gambling bail was $\$ 50$ in 1910; for example see State of Oregon v. Ah Sing, JR 5389 (Clatsop County Cir. 1910).

${ }^{48}$ For the story about Lum Gut, also known as Charley Lee, see "Charley Lee," Morning Astorian, Sept. 10, 1918, p. 1; for the editorial supporting Chinese lotteries, see Morning Astorian, Oct. 31, 1902,
} 
Chinatowns. Ivan Light has argued that vice operations helped to make Chinatowns dirty. Chinese quarters commonly provoked special alarm in U.S. cities, and this was the case in Astoria as well. ${ }^{49}$ Local newspapermen and other European Americans highlighted Chinatown's filth and advocated attempts to clean up the neighborhood constantly from the 1880s through 1910s. Reform efforts materialized as early as 1888, with the filling of what the Daily Astorian referred to as "the stench ponds in Chinatown." ${ }^{50}$ The 1886 cubic air ordinance and arguments against Chinese laundries further assumed the Chinese section's innate sordidness. Opium also played on white imaginations as a unique Chinese filth (though the British had introduced it to China to begin with). Locals' desire to extirpate the drug from the Chinese quarter precipitated multiple grand jury investigations in 1918. As reported by the Morning Astorian, jury members accompanied the mayor and chief of police in a tour of the area, finding "barricaded doors, filthy conditions and general surroundings tending to make crime and misdemeanors prevalent." ${ }^{51}$ In the back rooms of one tightly-locked building, the party also discovered two men in a drug-induced stupor, the paper emphasized. $^{52}$

p. 2.

${ }^{49}$ Charles J. McClain, In Search of Equality: The Chinese Struggle Against Discrimination in Nineteenth-Century America (Berkeley, 1994), 223. For a more in-depth treatment of medical alarm in San Francisco, see Nayan Shah, Contagious Divides: Epidemics and Race in San Francisco's Chinatown (Berkeley, 2001); and in Honolulu, James C. Mohr, Plague and Fire: Battling Black Death and the 1900 Burning of Honolulu's Chinatown (Oxford, 2005).

${ }^{50}$ Daily Morning Astorian, Nov. 25, 1888. The low-lying coastal land of downtown Astoria was rather marshy in the town's earlier days.

51 "Grand Jury Finds Men in Stupor," Morning Astorian, Oct. 28, 1919, p. 8.

${ }^{52}$ The field of medicine was quite unstable in the United States during these years as it worked out theories of disease, contamination, and other concepts. The somewhat widespread "miasma theory" 
Similarly, nineteenth-century Astorian newspapers often pictured Chinatown as a violent place. This was not unusual-Herman B. Chiu has found that papers across Oregon, in Jacksonville, John Day, and Baker City, in addition to Astoria, vilified local Chinese in the 1870 s and 1880s. ${ }^{53}$ News briefs told about the bomb that burned Hong Lee, the "bloody fracas" of a knife-armed mob, or the "sensational story" of a captured murderer sentenced to be entombed alive by the Chinese court. ${ }^{54}$ Selectively populating Astoria's Chinatown with explosive objects and residents, the papers reflected similar depictions in places like New York and San Francisco, fueling the notion that Chinatown was dangerous and degenerate.

Articles after 1900 suggest a progressive softening toward local Chinese in Astoria both in the newspapers and the larger white community. Chinese violence, for example, was both reported less often after 1900 and frequently compartmentalized as tong activity. ${ }^{55}$ The improvement of Chinese status in the Astorian media is most noticeable in the friendly reports about merchants that started cropping up after the turn of the century, often in the pseudo-gossip section of local briefs, while the more

held that diseases emanated in the air from infected material, making "stench ponds" and poorly ventilated opium dens especially alarming. See Nayan Shah's Contagious Divides for a more in-depth treatment of the American medical establishment as it related to Chinese immigrants.

${ }^{53}$ Herman B. Chiu, "Power of the Press: How Newspapers in Four Communities Erased Thousands of Chinese from Oregon History," American Journalism, 16 (1999), 59.

${ }^{54}$ Daily Morning Astorian, Feb. 10, 1891; Daily Astorian, Nov. 25, 1888; "Fate of a Murderer," Astoria Daily Budget, May 12, 1894, p.4; Weekly Astorian, June 27, 1885.

${ }^{55}$ In my survey of news articles between 1882 and 1924, 13 characterized Chinese as violent before 1900, while only 6 did after 1900, and half of the latter were in reference to a single incident of "tong warfare." Since tongs were regarded as mysterious criminal organizations, they could be differentiated from reputable Chinese. 
hostile portrayals declined. ${ }^{56}$ These new reports showed interest in the personal affairs of Chinese, paying compliments as if they were members of the community. These and other accounts revealed friendly interracial dealings that would have been unthinkable earlier. As early as 1903, the Morning Astorian covered the Chinese involvement in the annual Astoria Regatta, taking the time to name each Chinese committee member and excitedly advertising the coming of a ceremonial dragon as "one of the chief features" of the festival. ${ }^{57}$ The 1913 opening of a Chinese school received similar press. The Daily Budget ran a relatively long article announcing the institution's inauguration, detailing its proposed curriculum and summarizing the opening ceremony, even picturing the new instructor. The paper went on to mention the involvement of white community members with the school on several occasions in the next four years. ${ }^{58}$

Different conclusions can be drawn from this turnabout in Chinese fortunes, and it is not the case that their status turned upside-down overnight. Racial ideas continued to evolve during this period, with the appearance of new relationships and changes in old ones. Persistent hostility toward Chinese as well as other immigrantsexemplified by the groundbreaking Immigration Act of 1924—remained an undercurrent. In 1894 the Budget complained of immigrants representing "the offal of

\footnotetext{
${ }^{56}$ Nash, Two Years In Oregon, 214 - 15. According to Nash, the local briefs were extremely popular, the most widely read section of the newspapers.

${ }^{57}$ Morning Astorian, April 19, 1903; Morning Astorian, April 28, 1903.

${ }^{58}$ Astoria Daily Budget, Aug. 1, 1913, p. 6; Astoria Daily Budget, Sept. 17, 1913, p. 2; Astoria Daily Budget, Sept. 27, 1913, p. 6; Astoria Daily Budget, Feb. 2, 1914, p. 6; Astoria Daily Budget, Jan. 23, 1917 , p. 5.
} 
all Europe"; in 1905 the Astorian saw foreign "criminals and paupers" in the cities, but a better class of immigrants locally, explaining that "the kernel of the situation is contained in the power of assimilation." ${ }^{59}$ Editorials about Chinese paper sons and Japanese laborers expressed concern over certain types of Asians as well, specifically the working class, which showed less signs of assimilation. ${ }^{60}$ Editors complained, "They do not understand our institutions ... and are guilty of the most atrocious crimes." 61

On the other hand, there was much less race prejudice against properly assimilated individuals who contributed to society in acceptable ways. "There are many Chinese of exceptional type in Astoria," noted the Budget in 1917. "They like Astoria and its customs best." ${ }^{62}$ A family-oriented, socially active merchant class was preferable to a large number of male workers who did not speak English as well or otherwise conform to many social and cultural norms. As Sucheng Chan briefly stated, "Americans simply found the higher-class Chinese more acceptable." ${ }^{63}$ Some Chinese also shared this sentiment, as exemplified by comments from the Secretary of the Chinese Consulate-General at New York recorded in $1928 .{ }^{64}$

\footnotetext{
${ }^{59}$ Astoria Daily Budget, May 11, 1894; Morning Astorian, June 10, 1905, p. 2.

60 "Paper sons" were Chinese who immigrated on fake papers that falsely claimed merchant-son status.

61 "The Wiley Chinese," Daily Astorian, July 16, 1895; "Foreigners Coming," Astoria Daily Budget, June 9, 1905.

62 "Astoria Chinese Entertain American Citizens at New Year Banquet Saturday Night," Astoria Daily Budget, Jan. 29, 1917.

${ }^{63}$ Sucheng Chan, "The Exclusion of Chinese Women, 1870 - 1943," in Sucheng Chan, ed., Entry Denied: Exclusion and the Chinese Community in America, 1882 - 1943 (Philadelphia, 1991) 138.

${ }^{64}$ Eliot Grinnell Mears, Resident Orientals on the American Pacific Coast (Chicago, 1928), 12. Secretary J.S. Tow asserted that it was "unfortunate that the Chinese who first came to the United
} 
Officials in the U.S. government also shared a similar class bias, and here it became not just a social prejudice but also affected legal procedures and immigration. In the immigration case files, specifically, emerges an overlap of social bias with official procedure that moved sentiment into action. In this particular setting, class bias played out differently than it did in the newspapers-while news accounts highlighted the difference between the merchant and laboring classes, interactions in the immigration office revealed bias most clearly in officials' efforts to differentiate those Chinese who participated in merchant firms. As the local Chinese laboring population declined in the years approaching 1924, concern disappeared from the newspapers, while the continued presence of merchant operations led the same concern to increasingly manifest in the immigration office.

States were of the laboring class" because the laborers had left "a very unfavorable impression upon the American public." 
Chapter Three - Astoria's Immigration Office

Even as Chinese found Astoria becoming socially friendlier from 1882 to 1924, they faced rising difficulties with the local immigration office. Exclusion legislation vastly complicated immigration procedures by the 1920s. The "Chinese inspectors," those immigration officials specifically assigned to Chinese cases, wielded great power on the local level. They proved important obstacles for immigrants as well as valuable allies in cases where they showed special favor to merchants they deemed respectable.

Under the exclusion laws that began in 1882, Chinese laborers were not allowed to enter the United States. Those who arrived previous to November 17, 1880 , could leave and return if they obtained a special certificate. This right to return was revoked in 1888, but an 1894 treaty provided for the legal return of laborers who could claim one thousand dollars in property or debts owed, or who had a wife, child, or parent living in the United States. ${ }^{1}$

Different certificates could also be obtained by merchants and other exempt classes of Chinese, allowing them to both immigrate and return after subsequent trips abroad. $^{2}$ After 1892, Chinese legally in the United States were also issued certificates

\footnotetext{
${ }^{1}$ Lucy Salyer, 'Laws Harsh as Tigers": Enforcement of the Chinese Exclusion Laws, 1891 - 1924,' in Sucheng Chan, ed., Entry Denied: Exclusion and the Chinese Community in America, 1882 - 1943 (Philadelphia, 1991), 60.

${ }^{2}$ Other exempt Chinese included diplomats, teachers, students, and tourists.
} 
of residence, later called certificates of identity, precursors to the green card. ${ }^{3}$ In the immigration office, inspectors would check the certificates, but these did not ultimately determine entry, as officials took for granted rampant fraud. Instead, inspectors personally determined admission and re-admission to the country in most cases. In the absence of many verifiable facts, approval largely depended on the consistency of testimonies and impression of veracity made by the applicant and witnesses during an extensive interrogation. ${ }^{4}$ Chinese frequently used the court system to appeal unfavorable decisions, with some success, until a 1905 Supreme Court decision took away the option of appealing decisions by bureau officials. ${ }^{5}$

Administrative factors also increased the difficulty of immigration for Chinese after 1900. From that year to 1903, a transition of exclusion enforcement took place from the Customs Service under the Treasury Department to the Bureau of Immigration under the Department of Commerce and Labor. Scholars disagree on the details of this change; the Bureau of Immigration took responsibility for exclusion matters in either 1900 or 1903, and moved to the Department of Commerce and Labor in the latter year. This consolidated Chinese immigration administration with that of general immigration, and, according to Lucy Salyer, weakened the impact of judicial

\footnotetext{
${ }^{3}$ Erika Lee, At America's Gates: Chinese Immigration During the Exclusion Era, 1882 - 1943 (Chapel Hill, 2005), 42.

${ }^{4}$ As the exclusion administration developed, interrogations became much longer in the 1910s and 1920s compared to earlier years. See Estelle Lau, Paper Families: Identity, Immigration Administration, and Chinese Exclusion (Durham, N.C., 2006), 47, 51, and 71.

${ }^{5}$ Lee, At America's Gates, 68.
} 
review in exclusion matters. ${ }^{6}$

Nineteenth-century records of Chinese immigration to Astoria are scant and indicate a loose enforcement of exclusion laws before the Bureau of Immigration took over in 1900 and was restructured in 1903. The National Archives has three customs books covering select years between 1882 and 1894 and no records from 1894 to 1900. The books are not well organized, as the contents do not match the dates recorded on the covers and most of the pages are blank. The first book spans September 1882 to December 1885, and the back pages list merchant certificates from March 1889 to August 1890. The second volume begins in October 1885 and runs through April 1890, and the third contains records from June 1891 to May 1893, plus merchant certificates from December 1894 through the end of 1903. In these books, each individual occupies one line, along with a subsequent string of likewise handwritten statistics: age, occupation, last place of residence, height, complexion, color of eyes, physical marks, dates of arrival and departure, names of arriving and departing ships, and a final section for general remarks, which is usually empty. Most applicants from the 1880 s do not have their full name recorded, as officials listed about one-third of them with one name beginning with the Chinese title "Ah," such as Ah Chow, Ah Lee, Ah Lum, and so on. Physical descriptions grew more detailed in the late $1880 \mathrm{~s}$, but there remained a general dearth of commentary on cases into the

\footnotetext{
${ }^{6}$ Compare Marie Rose Wong, Sweet Cakes, Long Journey: The Chinatowns of Portland, Oregon (Seattle, 2004), 76 - 78; Lee, At America's Gates, 68; Lau, Paper Families, 19, 32, and 104; Salyer, 61 and 77 . See chapter one, note 22 for an outline of the administrative structure of exclusion policy.
} 
1890s. Officials denied few applications, which were noted but not explained in the books. In 1884, officials refused the landing of less than 2 percent of applicants; in 1885, less than 1 percent. In contrast, after 1900 the Immigration Bureau inspectors denied 17 percent of applicants. ${ }^{7}$

"Chinese inspectors" were the primary government apparatus for the local execution of exclusion policy after 1900. Specifically assigned to handle Chinese cases by the Bureau of Immigration, these inspectors held posts in major cities such as Seattle, Portland, and San Francisco; smaller offices were established in ports such as Sumas, Washington, and Astoria. Astoria's role in processing immigrants became less prominent in the late nineteenth century. Portland emerged as the regional hub instead, and Astoria's inspectors functioned as subsidiaries of the Portland office. Local officers reported to the inspector-in-charge at Portland in all Chinese cases, a chain of command that produced some delays, both intentional and accidental, though the daily Portland-to-Astoria postal service usually sufficed for processing to be conducted expeditiously. In any case, the local inspectors continued to be the ones who interfaced with Astoria's Chinese community on behalf of the government.

The importance of local inspectors derives from trends in both immigration administration and the Chinese immigrant community. Despite the bureaucratic limits of their authority, in practice the inspectors exercised a large amount of leverage in

\footnotetext{
${ }^{7}$ Records of Chinese Arriving, Astoria, Oregon, from Oct. 1st, 1893 to July 11, 1903, Box 6, Portland District Office, Records of the Immigration and Naturalization Service, Record Group 85, National Archives and Records Administration-Pacific Region (Seattle). In 1884, 12 of 760 applicants were
} 
the processing of individual cases, and their judgment in turn impacted the result of each case, while their perspective, insight, and openness shaped the resulting records that we now have available. As Chinese immigration historian Estelle Lau puts it, the loose and evolving nature of the system during these years left "an overwhelming amount of discretion" in the hands of immigration officials. ${ }^{8}$

The migratory habits of Gold Mountain men and women magnified local officials' authority. As Madeline Hsu has shown, southern Chinese had a wellestablished pattern of traveling for work by the 1880s, both within China and internationally. ${ }^{9}$ Strong ties to their homeland, aided by a strong organization abroad, led to a high rate of back-and-forth travel by overseas Chinese. This is evident in the U.S. immigration records, which show the merchants, especially, making frequent trips across the Pacific. Leong Yok Lun, for example, applied for five roundtrips to China between 1917 and 1930; Chan Ah Dogg made five trips between 1912 and 1923; Low Fay traveled in 1902 and $1907 .{ }^{10}$ All this activity made for a continual reapplication of immigration policy throughout an individual's life as he or she moved across borders to the dictates of family and business.

The frequency of Chinese merchants' travels put them in constant contact with

refused, while in 1885, officials refused only 2 of 320. The Immigration Bureau inspectors denied 27 applicants in the 159 cases that I checked between 1900 and 1924.

${ }^{8}$ Lau, Paper Families, 71; Lucy Salyer, Laws Harsh As Tigers: Chinese Immigrants and the Shaping of Modern Immigration Law (Chapel Hill, N.C., 1995), xiv, 32, 39 - 40.

${ }^{9}$ Madeline Y. Hsu, Dreaming of Gold, Dreaming of Home: Transnationalism and Migration Between the United States and South China, 1882 - 1943 (Stanford, 2000), 22 - 24.

10 "Leong Yok Lun," Case File 5009/184, Box 59, RG 85, NA; "Chan Ah Dogg," Case File 5009/201, Box 60, RG 85, NA; "Low Fay," Case File 1009/93, Box 41, RG 85, NA. 
immigration officials, and it was a complicated relationship for both sides. ${ }^{11}$ The restrictive goals of exclusion policy put the inspectors at odds with the Chinese, who required freedom of movement to maintain trans-Pacific lifestyles. The Chinese had to deal with paperwork, unfriendly policies, suspicious officials, incessant interrogations, and other red tape, while officials faced bureaucratic inefficiencies plus a wealth of unverifiable information and applicants and witnesses whose words could not always be trusted. With protocol only taking them so far, the rest was left up to officials' best judgment. Immigration case files from Astoria demonstrate that most Chinese immigrants in Astoria were able to successfully navigate this gateway relationship, a success that was sometimes hindered and sometimes helped by local inspectors.

Portland's most prominent inspector-in-charge in the first two decades of the twentieth century was John H. Barbour, an unfavorable appointment for Chinese Astorians. ${ }^{12}$ Barbour listened to local inspectors in most cases; however, despite the limitations imparted by his location in Portland, Barbour often contradicted the betterinformed local inspectors in Astorian cases. His strict attitude may have prevented some fraudulent applications from slipping past the inspectors but also revealed a basic insensitivity to the human side of the whole process. Even the inspectors in Astoria were not particularly fond of him, judging from their correspondence, and this

\footnotetext{
${ }^{11}$ Salyer, Laws Harsh As Tigers, 37.

${ }^{12}$ Wong, Sweet Cakes, 84. Barbour served as both an inspector and inspector-in-charge between 1898 and 1916, spending fifteen of those years in Portland.
} 
coincides with what Marie Rose Wong has found about his career in Portland. In fact, Wong seriously calls into question Barbour's competence on multiple levels. Her conclusion is based mostly on accusations by Portland's Chinese Consolidated Benevolent Association and a stenographer named Fessenden Chase, the former accusing Barbour of abusing his official powers and depriving Chinese of their rights, and the latter charging him with incompetency, inefficiency, egotism, disregard of protocol, and unexcused absences. "He thinks he is about the biggest thing in the way of a government officer that ever happened," Chase wrote. "On account of the public dislike that he has incurred at this station, he has rendered himself unfit to properly discharge the duties involved upon him."13

Barbour oversaw at least seven Chinese inspectors in Astoria in the two decades after 1903, the most prominent being Raphael P. Bonham. Opinionated and conscientious, Bonham served in Astoria's inspector's office as early as 1903 and as an inspector-in-charge in Portland by 1912, appearing in the case files in both cities until at least 1922. In these capacities he was involved with more local cases from 1900 to 1924 than any other inspector. ${ }^{14}$ A keen investigator, Bonham drew on personal knowledge of the local Chinese community to inform his decisions and seems to have been far more in touch in this respect than Barbour. He was also less hostile to the immigrants. In a 1908 letter, for example, Bonham indicated a surprising

\footnotetext{
${ }^{13}$ Wong, Sweet Cakes, 86 - 87, 93 - 97.

${ }^{14}$ Of the files that I accessed for Chinese cases in Astoria between 1900 and 1924, Bonham had a part in more than one-third.
} 
reluctance toward exclusion policy, specifically the statute requiring Chinese laborers to display at least one thousand dollars in assets to acquire a return certificate for foreign travel. "I feel that this is an unduly severe and useless law," Bonham opined in the case of Lum Yook, a laborer, "but as long as it is the law I can make no other recommendation." ${ }^{15}$ Bonham's comments do not display the vehement anti-Chinese stereotype that historians have found elsewhere. His perspective contrasted sharply with the Immigration Bureau's official opposition to working-class Chinese, manifested in this case by Barbour, who demanded the report be rewritten with all comment on the law extirpated. The case files do not completely tell how well the two men got along professionally, but for his part Bonham sensibly acquiesced, furnishing another report with only a dry concluding comment: "in future [sic] I shall try to prevent any suggestion of human interest or feeling from improperly creeping into my reports or recommendations."

Serving alongside Bonham from 1903 to 1908 was George W. Larner. Larner was a determined investigator, although not very effective, for several reasons. First, his willingness to employ Lum Ah Quinn, a notoriously dishonest individual, as an official interpreter casts doubt on Larner's judgment skills as well as the reliability of testimony he took in such cases. Second, Larner frequently queried witnesses on subjects in which they could not possibly have firsthand knowledge, with questions

\footnotetext{
15 "Lum Yook," Case File 1551, Box 3, Portland District Office, Chinese Exclusion Acts Case Files, 1891 - 1943, Records of the Immigration and Naturalization Service, Record Group 85, National Archives and Records Administration-Pacific Region (Seattle) (Hereafter cited as RG 85, NA).
} 
such as, "Did your mother have a white doctor when you were born?" ${ }^{16}$ At other times he took falsehoods or facts that the witness was clearly not ready to admit and stated them as questions, creating dialogues like this: "When did Leong Yick Duck sell out his share?" "He did not sell out."17 This was a tactic employed by immigration officials in the absence of reliable evidence-since they were unable to substantiate reports of activity in China, speak the Chinese language, or even rely on records in many cases, officials had few tools to weed out disingenuous applicants. The resulting method that developed over time was to intensify and prolong interrogations in order to tease out inconsistent testimony by cross-verifying everything that was said. Larner stands out for his use of this strategy before the 1920s, when it became a much more common practice in the Astoria office. Unfortunately, it was not a very reliable way to uncover lies, and officials other than Larner occasionally admitted as much. Despite his efforts, I found no evidence that it worked for Larner or any of the other inspectors.

A third way in which Inspector Larner compromised the effectiveness of his office was by taking innocence for granted in certain cases. While the "innocent until proven guilty" principle is a pillar of the U.S. judicial system, it was not a central tenet of Chinese exclusion enforcement. Moreover, if the statistics that historians like Madeline Hsu point to are even remotely correct, inspectors would have done well to

\footnotetext{
16 "Seid Tong," Case File 4382, Box 32, RG 85, NA.

17 "Leong Yick Duck," Case File 1009/85, Box 41, RG 85, NA.
} 
assume some kind of fraud in most cases. ${ }^{18}$ However, in contrast to the rigor of some of Larner's investigations, the inspector assigned special favor to successful businessmen. For one Lee Wah Sing he even initiated a second investigation in order to secure a merchant's return certificate for the applicant. ${ }^{19}$ Larner thus illustrated alternately the draconian nature of Chinese exclusion policy and the favoritism of its enforcement. $^{20}$

Following Larner was Earl Thomas Gooch, who worked in the immigration office from 1911 into the 1920s. The second-most frequent inspector handling cases in Astoria, after Bonham, Gooch is notable as the only inspector to admit ignorance in novel situations and ask Portland for advice. He comes across as a well-reasoned official who performed his job capably without unnecessary animosity toward the Chinese. Like other inspectors at the station during this period, he was usually willing to give applicants, laborers as well as merchants, the benefit of the doubt if everything seemed aboveboard. From Gooch's writings it seems clear that he did not do this blindly, but was astute and flexible enough to evaluate applicants based on the information available and the other Chinese involved in the case.

A revealing example of inspector Gooch's work is found in the file of Seid

\footnotetext{
${ }^{18} \mathrm{Hsu}$, Dreaming of Gold, 68 and 206. In the absence of official federal statistics on the matter, Hsu cites American estimates and one small Chinese account, both indicating that about eighty or ninety percent of Chinese immigrants entered the country on fake papers. See also Lau, Paper Families, 69 and Chan, Entry Denied, 71. The veracity of these statistics has been questioned based on the bias of the sources, but this does not necessarily make them false.

19 "Lee Wah Sing," Case File 5010/700, Box 74, RG 85, NA.

${ }^{20}$ See Bob Couch, "Family of George Hutcheon \& Jane Gall," hosted by RootsWeb, http://freepages.genealogy .rootsweb.ancestry.com/ bobcouch/hutcheons/. Larner may simply have
} 
Tong, who applied in 1915 for a return certificate as a U.S.-born citizen. This was a difficult case because there were no records that established with certainty Tong's birth and identity. The inspector also suspected a merchant named Seid Que of orchestrating the application, as Que in the preceding year had made several attempts to push fraudulent deals through the immigration office. There were also about a dozen witnesses, ranging in credibility from the trusty sometime federal interpreter Kong Sai Get to an obviously mendacious physician whose testimony Gooch described as a "farce." When Commissioner Barbour reasoned that the testimonies of Tong and Que nullified those of the more reliable witnesses and denied the application, Gooch willingly conducted a full investigation into Tong's reapplication, asserting that the applicant deserved a second chance and noting that Que had lost favor with local Chinese after they accused him of reporting their activities to authorities. After sifting through more witnesses, Gooch concluded the second investigation with a recommendation in Tong's favor, and when that was denied the inspector cooperated in providing information for Tong's lawyer. In his willingness to weigh testimonies and consider the situations of individual Chinese, Gooch comes across as a very reasonable inspector, especially in contrast to Barbour. So while Larner illustrates ways in which the inspectors could be ineffective, Gooch shows us that the immigration officials could also try to understand the local Chinese and treat

been trying to avoid complications at the end of his twenty-five-year civil service career. He retired in 1907, moved Washington state and lived out his days apple farming near Wenatchee. 
them fairly. ${ }^{21}$

A few other inspectors took a handful of Chinese cases in Astoria during this period-B.F. Crawshaw, Charles Reily, Roy J. Norene, and a few others. These individuals' presence is too limited to tell us much. Crawshaw served during Bonham's earlier years, Reily primarily handled cases during 1912 and 1913, and Norene assumed the office around 1919 and continued with the Immigration Bureau into the 1930s alongside Bonham. Judging from patterns in the case files, it is safe to assume that Norene became the regular Chinese Inspector, while others like Crawshaw appear to have been temporary stand-ins. Many cases were handled by more than one inspector, thanks to the turnover within the immigration office and the length of cases, which could extend for many months.

Besides the inspectors, the immigration office used temporary employees for typing and interpreting during interviews, a reflection of the lingering informality within overseeing agencies in the decades around 1900. The stenographers, who simply put each interview into type, are largely invisible in the case files, aside from the rare textual note. They tended to be women, but otherwise the case files contain little information on them and they seem to have played a small role in the actual development of each case.

Interpreters had a larger influence on immigration cases than stenographers, thanks to two factors. Interpretation precluded accountability in this setting-with

\footnotetext{
21 "Seid Tong," Case File 4382, Box 32, RG 85, NA.
} 
inspectors and stenographers who did not know the Chinese language and Chinese applicants possessing limited English skills, no one was able to verify the accuracy or integrity of the interpreters' work. Given the Chinese immigrants' general acuity in exploiting gaps in the immigration process, it is both reasonable to assume that at least some degree of corruption took place via the interpreter's tongue, and quite surprising that the inspectors would turn a blind eye to such risk. The risk was especially great in light of the second reason for the interpreters' relative significance: since they were all Chinese, the interpreters were de facto double agents in a scenario where applicants and officials operated with competing goals. The interpreters had their own personal stake in the immigration process as fellow compatriots, merchants, and travelers whose lives were affected by the same laws as were the applicants. San Francisco's office attempted to remedy this incongruity in the late 1890 s by means of hiring only white interpreters, but no such effort occurred in Astoria. ${ }^{22}$

One notable Astorian Chinese interpreter, Lum Ah Quinn, embodied the double agency of his job. An Astoria resident starting in 1890, Quinn interpreted for inspector Larner in multiple cases between 1904 and 1906, a scenario that invites immediate suspicion given Quinn's remarkably low repute with the immigration service a few years later. ${ }^{23}$ Quinn's file shows a record of discord with the law, as he

\footnotetext{
${ }^{22}$ Lee, At America's Gates, 58. The San Francisco office made a return to hiring Chinese interpreters by 1899 , due to a short supply of Chinese-speaking whites. While it lasted, the switch to white interpreters does not seem to have resulted in less corruption.

${ }^{23}$ For instance, Quinn was called to interpret in the following cases: "Ju Gong," Case File 1009/16, Box 39, RG 85, NA; "Lem Chan," Case File 1016/38, Box 44, RG 85, NA; "Leong Nang," Case File 1009/29, Box 40, RG 85, NA.
} 
deceitfully testified for other Chinese wishing to leave and re-enter the country, was arrested for illegal alcohol manufacture, and was once charged for disorderly conduct by the chief of police. ${ }^{24}$ He also began housing prostitutes about 1896 , and generally had "a sneaking way about him" according to an officer who arrested him in 1917. The case files show no fraud by Quinn during his interpreting work, but his activities point to an underlying conflict in the interpreter's position.

The two most prominent interpreters other than Lum Ah Quinn both enjoyed good reputations with the immigration office as respectable members of the Chinese merchant class. Seid Gain was involved in immigration cases from 1903 until at least 1915. Born into Portland's Chinese merchant elite, his father Seid Back was a convicted smuggler but a nonetheless a highly influential businessman and civic figure. ${ }^{25}$ Gain resided principally in Portland and became a significant figure in his own right, serving as president of the American-Born Chinese Association and captain of the American-Born Chinese Brigade, helping with his father's business, and working as a government interpreter after 1900. This latter occupation brought him into Astorian cases at least between 1903 and 1907, at which point he was promoted to a sort of overseer position in which he identified malpractice on the part of other

\footnotetext{
${ }^{24}$ An example of Quinn's illicit behavior is found in "Wong Hing Fow," Case File 1505, Box 2, RG 85, $\mathrm{NA}$; in this case, Quinn eventually admitted to Bonham that the applicant was not a legitimate merchant. Quinn's disorderly conduct charge is recorded in his own file: "Lam Quinn," Case File 5001/9, Box 50, RG 85, NA.

${ }^{25}$ For more of Seid Back, see Wong, Sweet Cakes, 181 - 184; additional details regarding one of Back's smuggling operations can be found in Sarah Griffith, "Border Crossings: Race, Class, and Smuggling in Pacific Coast Chinese Immigrant Society," The Western Historical Quarterly 35, (2004), para. 35 41, http://www.historycooperative .org/journals/whq/35.4/griffith.html.
} 
Chinese interpreters. ${ }^{26}$ This indicates that he himself used the powers of the office in a legitimate manner, and Barbour corroborated this notion by noting Gain as "the best Chinese interpreter of Chinese extraction" he had ever met. Gain worked primarily as a merchant and attorney in Portland after 1908, essentially removed from the Astoria scene but appearing in cases there from time to time. ${ }^{27}$

Inspectors hired locally after 1910 with Kong Sai Get, a labor contractor and member of several locally trading firms, including Mee Gin John. ${ }^{28}$ Sai Get enjoyed a degree of seniority, having been active in the local Mee Gin John store since 1894 and the Sam Lung Sing Company before that. ${ }^{29}$ Working for Mee Gin John meant he was probably one of the more financially stable Chinese in the city. In 1907, Astoria Savings Bank manager Frank Patton testified that the company was "first class, one of the strongest firms" in town. ${ }^{30}$ Sai Get also diversified his assets with foreign investments that included ownership of a Malaysian tin mine. Two sons added to the family prestige as well: the elder, Kong Sue Chong, served in the U.S. Army as a cook in 1918 and 1919, while his younger brother Kong Young Chong married Low Lin Wong, the sister-in-law of perhaps the region's most powerful Chinese labor contractor, Chan Ah Dogg. Once again, good social and business standing seems to

\footnotetext{
${ }^{26}$ I only found Gain interpreting in cases between 1903 and 1907, but it is possible that he worked outside of this timeframe as well.

${ }^{27}$ Wong, Sweet Cakes, 191 - 192. Barbour further lauded Gain as "the only interpreter in this state who is above the possibility of corruption."

28 "Lum Foon," Case File 4233, Box 31, RG 85, NA; "Kong Sue Chong," Case File 5017/88, Box 85, RG 85, NA. As with most Chinese names during the period, Mee Gin John assumed a number of different spellings in the English.

29 "Hong Bun," Case File 4769, Box 36, RG 85, NA; "Labor Contract for Chinese Workers on the
} 
have impressed the immigration office; Bonham regarded Sai Get with little suspicion, noting him as "one of the most genuine merchants in Astoria." ${ }^{31}$

Presumably this recommended Sai Get as a trustworthy interpreter. He worked numerous cases between 1910 and 1916, and was followed in sequence by a Chin Shing Gee and then Herman Low, both of whom left little imprint in the records with their interpreting work before the early 1920s.

Along with the inspectors, interpreters, and applicants, immigration cases often involved additional human variables. Witnesses, both white and Chinese, provided information in Chinese cases and heavily influenced the inspectors' recommendations to Portland. ${ }^{32}$ Two was the standard number of witnesses for each case, though cases with more suspicion attached could involve ten or more individuals testifying under oath. The number of general Chinese witnesses, whose real identities sometimes were not known, undermined some investigations. Cameo appearances in the case files are also made by lawyers. As scholars including Lucy Salyer, Sucheng Chan, Ivan Light, and others have demonstrated, Chinese immigrants by this time had became quite adept at using legal action in U.S. courts to their advantage. ${ }^{33}$ In Astoria,

Railroad to Astoria," Clatsop County Historical Society, Cumtux 22 (Spring 2002), 21 - 23.

30 "Kong Sue Chong," Case File 5017/88, Box 85, RG 85, NA.

31 Ibid.

${ }^{32}$ Some case files hold as little as one sheet of paper, but I assume that this is a matter of recordkeeping.

${ }^{33}$ Salyer, Laws Harsh As Tigers, 18 - 21, 106 - 110; Ivan Light, "From Vice District to Tourist Attraction: The Moral Career of Chinatowns, 1880 - 1940," Pacific Historical Review 43 (1974), 367 394; Lee, At America's Gates, 138 - 141; Charles J. McClain and Laurene Wu McClain, "The Chinese Contribution to the Development of American Law," Lucy Salyer, "'Laws Harsh as Tigers':

Enforcement of the Chinese Exclusion Laws, 1891 - 1924," Sucheng Chan, "The Exclusion of Chinese Women, 1870 - 1943," in Sucheng Chan, ed., Entry Denied: Exclusion and the Chinese Community in 
well-connected merchants often arranged applications for compatriots in the immigration office, and whether it was the cause or the effect of their success, certain merchants arranged more successful ensembles of characters than did others.

America, 1882 - 1943 (Philadelphia, 1991), 5, 61 - 65, and 94. 
Chapter Four - Merchant Firms, Immigration, and Race Relations

The immigration case files show more vigorous enforcement of exclusion laws as the 1920s approached. This was not due to growing antipathy toward the Chinese, but rather a continuation of the campaign against working class Chinese from the late nineteenth century. Merchants did face more difficulties in one sense, since they traveled abroad more often than laborers, but the changing procedures were actually an attack on false merchants. Officials treated favorably those whom they considered "good" merchants while working to weed out manual laborers who claimed to be merchants. They also tended to favor successful businessmen. To the inspectors, Chinese firms fell into three categories: those in good standing, those in poor standing, and an ambiguous group in the middle that did not fit entirely into either the "good" or "bad" category. In Astoria, companies such as Hop Hing Lung, Lum Quing, and Wah Sing established a rapport with the inspectors that led to their treatment as "good" merchants. Others, like Ark Wo and Yee On, sullied affiliates' interactions with the U.S. government simply by their reputations with local officials. In between, the more ambiguous firms' members drew varying levels of scrutiny, as the inspectors did not always know how to approach them.

Inspectors put a great deal of effort into delineating "good" and "bad" merchants and businesses, and acted on these impressions in the absence of better information. For the Chinese, this elevated the practical importance of impressing the 
inspectors over the need to actually comply with exclusion law. For the inspectors, on the other hand, it provided a basis for action but tied that action to precedent and hearsay. The inspectors' efforts affected a relative increase in denied immigration applications after 1900, but Chinese merchants in Astoria continued to gain approval in most cases, and even members of suspect firms were often able to succeed in the face of greater scrutiny.

The focus on Chinese class status in the immigration case files highlights the importance of merchants within the local Chinese community socially and economically. Socially, merchants enjoyed prominence in the immigrant communities in contrast to their lower status in China. ${ }^{1}$ They also experienced less racial prejudice than laborers. Immigration file testimonies regularly display cordial relations between Chinese merchants and members of the white middle and upper classes. Especially by the 1910s and 1920s, merchants could build reputations in ways that laborers could not. Familiarity contributed to the merchants' reputations, as did economic success.

Chinese merchants who succeeded had the resources to meet laborers' needs and performed a number of other crucial services for their compatriots besides offering employment. Numerous firms imported Chinese goods for immigrants' consumption that could not otherwise be found in the United States. Merchants also found work for laborers and kept important documents for those who traveled for

\footnotetext{
${ }^{1}$ Shehong Chen, Being Chinese, Becoming Chinese American (Urbana, Ill., 2002), 11. Chen notes that merchants sat relatively low on the social ladder in China, but gained status in the United States because of the immigrants' general economic mission. According to Yong Chen, Chinese authorities
} 
seasonal employment, as well as purchasing equipment for them and providing lodging. This all coincides with historian Madeline Hsu's description of a class of companies called "jinshanzhuang" that specialized in importing goods from China and provided international postal and banking services. ${ }^{2}$ Laborers depended heavily on merchants for their economic well-being, while becoming a merchant increased opportunities to build wealth and families.

Merchants' social and economic successes carried weight in the immigration office. Merchant firms helped individual Chinese to reach the immigration office in the first place, acting as legitimizing umbrellas for those desiring to travel. Business connections allowed travelers to secure positive testimony from reputable white witnesses; sometimes Chinese from different firms offered testimony for each other. Certain Chinese also built up business history working for multiple partnerships. Inspectors often remarked on the most successful merchants as if business acumen precluded attempts to evade immigration law. In this sense, interactions in the immigration office paralleled what we see in sources like the newspapers, where Chinese merchants gained acceptance as praiseworthy citizens. So, while exclusion enforcement measures generally increased in the early twentieth century, certain Chinese merchants evaded this trend thanks to their good relations with the white community.

disdained commercial occupations as inferior to sustenance agriculture. See also Yong Chen, Chinese San Francisco, 1850-1943: A Trans-Pacific Community (Stanford, 2000), 17.

${ }^{2}$ Madeline Y. Hsu, Dreaming of Gold, Dreaming of Home: Transnationalism and Migration Between the United States and South China, 1882 - 1943 (Stanford, 2000), 33 - 40. 
One of Astoria's most successful Chinese firms was Hop Hing Lung, a contracting and importing business buoyed by the influx of cannery labor that began in the 1870s. Labor contracting provided the company's major revenue stream; Hop Hing Lung supplied laborers to as many as eighteen canneries. "They are the largest contractors on the coast," affirmed Samuel Gordon, a cashier at First National Bank, in $1914 .^{3}$ There was also a company store at 376 Bond Street selling imported goods to local Chinese, and at least one of the firm's members received commissions for selling Canadian Pacific Railroad tickets to Chinese workers. ${ }^{4}$ Boarders, probably seasonal cannery hands, also rented bunks above the store. Overall, it was a profitable endeavor. Secretary Ing Wong estimated in 1909 that the firm imported goods to Astoria worth thirty thousand dollars annually; by 1920 the firm was trading close to sixty thousand worth per business year, equivalent to nearly five million dollars in 2009..$^{5}$

Hop Hing Lung's most prominent merchant was Chan Ah Dogg, an entrepreneur and cultural diplomat who rose to vice president and then president of the firm by $1915 .{ }^{6}$ A respected labor contractor, Dogg also owned the sixth lot of

\footnotetext{
3 "Ing Wong," Case File 4024, Box 30, Case File 5001/9, Box 50, Portland District Office, Chinese Exclusion Acts Case Files, 1891 - 1943, Records of the Immigration and Naturalization Service, Record Group 85, National Archives and Records Administration-Pacific Region (Seattle) (Hereafter cited as RG 85, NA).

${ }^{4}$ It is not clear whether Go Lung Kee was selling rail tickets under the banner of Hop Hing Lung, doing it for another firm, or simply working independently in this regard. In any case, Hop Hing Lung's members were well connected and represented a variety of business interests.

${ }^{5}$ Samuel H. Williamson, "Seven Ways to Compute the Relative Value of a U.S. Dollar Amount, 1774 to present," MeasuringWorth, http://www.measuringworth.com/uscompare/. Amount calculated as relative share of GDP.

6 "Chan Ah Dogg," Case File 5009/201, Box 60, RG 85, NA. Also known as Chin Ah Dogg, he was
} 
block ten off of Bond Street in Astoria, between 7th and 8th, and held interest in such ventures as the Portland-based Ong Hing Company, the Quong Yick Land Company, and a steam ship business running between San Francisco and China. According to the banker, Gordon, Chan personally conducted one hundred and fifty thousand dollars in business on a yearly basis in 1916, a figure that increased to exceed two hundred and fifty thousand only three years later, and the bank loaned him as much as ten thousand at once without security. ${ }^{7}$

In the process of his wealth-building, Dogg traveled frequently, shipping out to China at least every four years. His trips were facilitated by the local inspectors' glowing recommendations, as well as their apparent reluctance to scrutinize the details of his activities, making his file a model of the leniency afforded to successful and prestigious merchants. When Dogg's departure by way of Seattle in 1914 prompted the immigration commissioner there to order an investigation, Barbour pondered, "What is the purpose in subsequently investigating the case of Chin Ah Dogg when it appears of record that he holds a certificate of residence showing his right to be and remain within the United States, whatever be his occupation?" Bonham followed suit; after Dogg's next trip eastward in 1916 and 1917, Seattle once again requested an investigation in Oregon, but Bonham ignored the directive for nine months before forwarding it to inspector Gooch in Astoria, who responded five days

commonly referred to as "Dogg."

${ }^{7}$ This is anywhere between $\$ 2.4$ million and $\$ 45.5$ million, depending on the conversion method as calculated by Williamson, "Seven Ways to Compute the Relative Value of a U.S. Dollar Amount, 1774 to present," http://www.measuringworth.com/uscompare/. 
later in Dogg's favor without adding any testimony to the record. To Seattle Bonham nonchalantly explained that "an earlier report would have been submitted, but through some inadvertence your letter was filed and the matter overlooked." ${ }^{8}$ When authorities did actually investigate Dogg, there was no shortage of respectable witnesses; testimonies touched on his business ventures, uprightness, and good standing in the community.

Chan Ah Dogg's family life received some attention in the case files, but, true to form, the questioning on this topic was not as extensive as for lesser-known Chinese. Dogg had a family in Astoria, and officials treated its members with a similar cordiality, as evidenced in the files of Low Lin Yow, Dogg's wife, and Chan Oey Dogg, his eldest daughter. Dogg had married by Chinese custom in 1893 to Lin Yow, and the couple subsequently remarried by American law in February of 1906. Dogg then proceeded to take a second wife in China, prompting both marriages to be declared void in the United States, a situation only rectified in 1910 when Dogg and Lin Yow remarried again in the States. The latter had an entrepreneurial bent of her own; she held significant shares in both Hop Hing Lung and the Quong Hick Land Company, and in 1914 she applied for and received a merchant's return certificate upon leaving the country, rather than a merchant's wife's permit, for the purpose of ensuring her return should her husband die or be unable to make the return trip in a timely manner.

\footnotetext{
8 "Chan Ah Dogg," Case File 5009/201, Box 60, RG 85, NA.
} 
Dogg outlived his wife, but during their time together they raised two daughters and two sons. The oldest, Chan Oey Dogg, was born in 1897 and spent much of her youth in Astoria, where she attended McClure's school and a Sunday school at one of the local churches. ${ }^{9}$ Oey Dogg frequently translated for Dr. O.B. Estes when he treated Chinese clients, and translated for her mother in immigration cases as well. ${ }^{10}$ Chan Ben Hung, Oey Dogg's younger brother by seven years, seems to have spent most of his youth in China or Hong Kong, where he came into discord with his father. "I don't want his name mentioned," Dogg testified in 1923. ${ }^{11}$ In 1915 and 1917, respectively, the family grew by another girl, Chan Jang Hing, and a boy, Chan Wok Hung. The last two were still very young by the early 1920s, but the inspectors' conspicuously high regard for the family smoothed the older members' overseas travels considerably. ${ }^{12}$

Chan Ah Dogg enjoyed an unusually friendly relationship with the U.S. Immigration office and so did his colleagues at Hop Hing Lung. Most of them did not have credentials comparable to Dogg's, nor were most related to him, a notable fact in light of the degree to which Chinese immigrants relied on family organizations, where family included anyone sharing a surname. In Astoria, the Hop Yick Shing Kee Company, for example, was populated heavily with Leongs, as was the Yee On

\footnotetext{
${ }^{9}$ The records do not indicate which congregation provided the Sunday school; it was taught by Mrs. Turner, the wife of a cannery superintendant.

10 "Chin Oey Dogg," Case File 5017/64, Box 86, RG 85, NA; "Low Lin Wong," Case File 2629, Box 16 , RG 85, NA.

11 "Chan Ah Dogg," Case File 5009/201, Box 60, RG 85, NA.

${ }^{12}$ It is unclear from the case files whether Dogg's children were born in China or the United States.
} 
Company. Mee Gin John was composed primarily of Lums, and Wah Hing John consisted of mostly Wong clansmen. Hop Hing Lung, in contrast, was composed of numerous clans, including Chan, Lum, Wong, Leong, Ing, and Ju. The first four ranked among the preeminent Chinese business families in Astoria, so in a sense the company was a conglomerate corporation, bringing would-be competitors together under a single banner. ${ }^{13}$

There was only one Chan listed in the Hop Hing Lung books, but two members may have been relatives of Chan Ah Dogg: the aforementioned interpreter Chin Shing Gee, and Chin Back, "Chin" and "Chan" being two names that were often interchanged by English-speaking Americans. Though Chin Shing Gee left only a small footprint as an interpreter, the case files suggest that he was an influential capitalist. He did not join Hop Hing Lung until 1915, when he purchased Wong Hong Bong's share, but he had been working in the United States for twenty years before a visit to China in 1917 , which he made to bring his wife and daughter to the States. This immigration seems to have gone entirely in the applicant's favor, as Shin Gee secured testimony from a white cigar maker, druggist, and tailor, as well as from Dogg. When Inspector Gooch became shorthanded during the investigation, he opted to abbreviate the questioning rather than delay the process, and shortly thereafter issued a favorable recommendation. Shin Gee later adopted a boy, adding to his

\footnotetext{
13 "Low Leu Yow," Case File 4036, Box 30, RG 85, NA; "Leong Som Tuck," Case File 2241, Box 11, RG 85, NA; "Fong Hong," Case File 1896, Box 6, RG 85, NA; "Lum Bock Sun and Lum Shin Yuen," Case File 1669, Box 4, RG 85, NA; "Wong Fie," Case File 4784, Box 36, RG 85, NA.
} 
family status. Notably, Gee's family resided outside of the Chinese district, which could suggest acceptance from the white community or Chinese disdain for those who took employment with the Immigration Service. Either way, the relative ease with which Shin Gee was able to bring a family into the country supports the notion that he had ties to white power-holders in town and also points to a bias in favor of successful Chinese merchants, particularly those of Hop Hing Lung. ${ }^{14}$

Chin Back's case, twelve years before Chin Shing Gee's, had similar qualities from an immigration perspective. Chin Back had arrived in Astoria in 1884 as a twenty-seven-year-old and worked as a laborer for fourteen years. Then in 1898 he became an original member of Hop Hing Lung, a palpable rise in status. He was granted a merchant's return without delay or problem in 1903, and again in 1907; prior to his second trip, Back testified that he was in fact an active member, an important distinction since many shareholders in Chinese firms did not actually work for the business, and some even occupied themselves as laborers, the targets of exclusion law. ${ }^{15}$ By most accounts Hop Hing Lung carried about twenty shareholders before the turn of the century, but in 1907 Chin Back mentioned only Chin Fook Sing, $\mathrm{Ng}$ Wong, Leong Yip, and Dogg as active members besides himself, out of twentytwo total. This means that the other seventeen shareholding individuals were not directly involved in the business operations of Hop Hing Lung and were likely performing some type of manual labor, perhaps in a distant locale. However,

\footnotetext{
14 "Yip Fun Sue, Kim Ho, Chin Ying," Case File 5011/21, Box 75, RG 85, NA.
} 
technological limitations made it difficult for authorities to keep track of every member's whereabouts, much less his economic habits, and inspectors depended heavily on testimony from parties who, like Chin Back, were deemed reliable sources of information. Back secured influential witnesses, including Dogg, Charles Page, and Charles Brown. Being an original member of Hop Hing Lung probably worked in his favor.

Ju Gong claimed seniority as the founder of Hop Hing Lung; he, too, had no problems in his case files. After being involved in the Hong Yick Company, Gong had lived at the location of the Hop Hing Lung company store for thirteen years prior to opening the business in $1898 .{ }^{16}$ Gong secured the testimony of Victor Boelling, a member of Astoria's white elite, who had provided the town's first school with a building in 1851. Boelling was familiar with Astoria's Chinese immigrants; since about 1880 he had rented property to them.

Familiarity was crucial for immigration officials as they attempted to identify and keep track of Chinese individuals who might be related, look alike, or have similar names. Consider the following three men who worked in some way with Hop Hing Lung: Ju Gong had lived in Astoria since at least the mid-1880s and founded Hop Hing Lung. He was a successful businessman with influence in the community. Just two years after Gong traveled to China in 1904, another merchant, Chew Kong,

\footnotetext{
15 "Chin Back," Case File 1009/94, Box 41, RG 85, NA.

16 The Hong Yick Company may have been, though was not necessarily, the same as the Quong Yick Land Company that Dogg partly owned. Though it is speculation on my part, it would not be a surprise considering Dogg's early and prominent involvement in Hop Hing Lung.
} 
applied for a return certificate. A Portland-based worker with the Gee Wah Bing Kee Company, his described business interests were somewhat divergent from Gong's, though Kong later did join Hop Hing Lung as a salesman and delivery man. In 1916, another man, named Jeu Jung, also applied for a trip to China as an employee of Hop Hing Lung. Jung had also been in the U.S. for several decades, but he was a cannery hand and netmaker. ${ }^{17}$ Given that it was not unusual for a Chinese man to have a childhood name, a married name, several English spelling variations, and maybe a nickname, indeed, given the prevalence of word and name confusion amongst white Americans when it came to Chinese, it is quite conceivable that a single person could be known as Ju Gong, Chew Kong, and Jeu Jung. Here there is no evidence to support the existence of a conspiracy on a scale involving one man assuming each of the three identities, but still it is easy to see how such a scenario could confuse officials' efforts to keep track of individual migrants.

Members in firms like Hop Hing Lung not only possessed similar names in some cases; sometimes they shared the same name. Though Hop Hing Lung was not a family business, blood ties permeated the organization. Aside from the Chins, the Ing and Wong clans each had a major presence in the company. Ing Fook and Ing How were both founding members of Hop Hing Lung, and it seems likely that Ing Wong, How's brother, was in the original group as well. It is not clear from the immigration files what sort of work Ing Fook performed, but he claimed to be an active member in

\footnotetext{
17 "Jeu Jung," Case File 5010/9, Box 60, RG 85, NA.
} 
both 1907 and 1920, and Low Lin Yow affirmed that he worked in the company store in 1910. Given his proficiency in English, it is likely that he dealt with non-Chinese customers and business contacts. ${ }^{18}$ Fook claimed American birth, as did Ing How, who was born in Portland in 1874. Two separate immigration files were produced for How, one in 1908 and one in 1914, and though neither developed much detail there is evidence of How's good status. No hint of controversy manifested in his travels, even in 1914 when he completely disregarded immigration protocol and exited the country without notice. Chan Ah Dogg's explanation, along with inspector Bonham's own personal familiarity with the departed applicant, made the hurried trip a cordial nonissue. ${ }^{19}$ Interestingly, though Wong claimed American birth like his two relatives, he followed in their footsteps and did not use citizenship as a means of returning to the country. The inspector even asked Wong why he bothered to apply for a merchant's return when he could travel as a U.S. citizen; Wong replied that he had traveled as a merchant before and now wanted the same. Further questioning revealed that Fook and Wong did not actually possess birth certificates. Fortunately for Wong, his prevalence in testimonies as the Hop Hing Lung secretary and store manager, added to the strength of the company's reputation and his acquaintance with the inspectors, sufficed to conveniently smooth his immigration process. ${ }^{20}$

Ing Wong is also noteworthy because, while he belonged to the Ing clan, he

\footnotetext{
18 "Low Lin Yow," Case File 2154, Box 10, RG 85, NA; "Ing Fook," Case File 5009/68, Box 56, RG 85, NA; "Ju Gong," Case File 1009/16, Box 39, RG 85, NA.

19 "Ng How," Case File 3871, Box 29, RG 85, NA; "Ing How," Case File 1009/103, Box 41, RG 85, NA.
} 
also shared the Wong name. The Wongs were a prominent part of Hop Hing Lung individually and collectively, as the Wong's business involvement in Astoria rivaled that of any other Chinese clan in the city. In Hop Hing Lung, Wong Sang worked as a foreman, Wong Ngui Gen was a clerk, and Wong Joe became the manager, all shortly before or after $1920 .{ }^{21}$ Sang and Joe also both managed to bring a wife and children from China, and Joe served as a trustee for the estate of Wong Wing Sing, another Hop Hing Lung merchant who died suddenly in 1920, leaving his family with a small fortune-nearly twenty-six thousand dollars, the equivalent today of almost one-anda-half million dollars. ${ }^{22}$

Perhaps the most accomplished Wong in Hop Hing Lung was Wong Fook Lam. He reported the same birth year and location as Ing How, and at age thirty-three in 1907 was living over the company store. He did not apply for merchant status that year, though he was wealthy enough to make a trip to China as a shareholder in both Chan Ah Dogg's Quong Yick Land Company and Hop Hing Lung. Already a labor contractor in 1907, by 1910 Fook Lam was the foreman at the Kinney cannery in downtown Astoria. Bonham attested in 1907 that Fook Lam was "well and favorably known to many white people here, has the reputation of being well to do [sic], and his

\footnotetext{
20 "Ing Wong," Case File 4024, Box 30, RG 85, NA.

21 "Wong Sang," Case File 4383, Box 32, RG 85, NA; "Wong Ngui Gen," Case File 5009/171, Box 59, RG 85, NA; "Wong Gong," Case File 5010/399, Box 68, RG 85, NA.

${ }^{22}$ Samuel H. Williamson, "Seven Ways to Compute the Relative Value of a U.S. Dollar Amount, 1790. This calculation was made using the GDP per capita conversion. to Present," MeasuringWorth, http://www.measuringworth.com/uscompare/. The gross domestic product (GDP) per capita conversion measures Ing's income relative to the earnings of the rest of the population. Converting his income in terms of purchasing power results in a sum about five times
} 
connection with the canneries is unquestioned." ${ }^{23}$ Various testimonies refer to Fook Lam filling the roles of manager and treasurer of Hop Hing Lung, and by 1920 he sat as president and was a principal shareholder. Together with his wife Grace Wong Lam, ${ }^{24}$ he raised ten children; he also lodged a younger cousin, Wong Hong Bong, whom he helped to return from a roundtrip across the Pacific in $1921 .^{25}$ Fook Lam later turned exclusively to labor contracting in a profitable partnership with his old friend Dogg, for which the latter deposited funds in excess of one hundred and sixty thousand dollars in $1926 .^{26}$

While concentrating his business interests helped Wong Fook Lam to become wealthy, another Hop Hing Lung member, Leong Yip, spread his investments across several local firms, with mixed results. Yip held shares in the Yee On Company and the Hop Yick Shing Kee Company besides Hop Hing Lung, and it appears that Yip's role in the latter was limited to that of a shareholder rather than an active partner. Still, his presence in the firm is curious as he was the only Leong in the business, and the other companies he associated with differed markedly from Hop Hing Lung in terms of reputation. Yip was something of an elder statesman in Chinatown, testifying frequently for his compatriots, and his closeness to cases and companies involving illegal immigrants illustrates the difficulty that immigration officials faced in

smaller, while using his relative share of the overall GDP results in an amount roughly three times larger.

23 "Wong Fook Lam," Case File 5010/577, Box 72, RG 85, NA.

24 "Herbert Wong et al.," Case File 5017/92 - 97, Box 85, RG 85, NA.

25 "Wong Hong Bong," Case File, 5009/207, Box 60, RG 85, NA.

${ }^{26}$ Today's equivalent to about nine million dollars using the GDP per capita conversion; "Chan Ah 
separating trustworthy and suspect Chinese. Though no legal action seems to have been taken against Yip, inspector Larner confessed a propensity to "look askance at any case in which he is particularly interested." ${ }^{27}$ Evidently Yip's connection with Hop Hing Lung was thin and did not mar the company's solid image, but his presence as a disreputable character does add an element of uncertainty to the firm's otherwise solid reputation.

Immigration records paint Hop Hing Lung as the most highly regarded Chinese firm in Astoria. By building a reputation for success, cooperation, and honesty, its members established an exceptionally amicable relationship with the immigration office, and as a result they never had problems traveling overseas or importing family members. "It is so seldom," inspector Bonham reported in 1919, "that we have found in our years of handling Chinese cases a firm who has never attempted, in so far as we know, to impose upon this service in the way of bringing in fictitious members that I feel it due this applicant and his firm to state that, since the establishment of this office, the firm of Hop Hing Lung Co. has maintained a clear record." ${ }^{28}$ In an era of heightened anti-Chinese suspicion, such an unqualified endorsement bestowed exceptional freedom on the firm's members, and may even have contributed to their collective business success. It also clearly belies any notion that immigration officials treated all Chinese with the same low regard.

Dogg," Case File 5009/201, Box 60, RG 85, NA.

27 "Leong Yok Lun," Case File 5009/184, Box 59, RG 85, NA.

28 "Chan Ah Dogg," Case File 5009/201, Box 60, RG 85, NA. 
Other Chinese companies built positive images as well; firms like Lum Quing, Wah Sing, the Astoria Restaurant, and Dock Lung all cultivated an air of respectability that put them on good terms with authorities, allowing their members to travel and bring relatives from overseas with reduced scrutiny, and to conduct business as usual with the inspectors' stamp of approval. Though they conducted a variety of business activities, their merchants amassed immigration records similar to that of Hop Hing Lung.

Relations with the white community were especially important for the merchants at Lum Quing and Brother, later the Lum Quing Grocery Company, that operated at 373 Bond Street. The firm sold "American" groceries, including dry goods and a wide variety of nuts, fruits and vegetables. Lum Quing himself had been a laborer until 1906, when he went into business with his brother Lum Sue. The latter had arrived in town from northern California that year in the wake of the San Francisco earthquake and fire, which obliterated the city's Chinatown. ${ }^{29}$ Together the brothers catered to a primarily white clientele, and the business was so good that Sue opened a second store down the street at 253 Bond, the American Grocery Company. ${ }^{30}$ Given the proximity of the second store, it would not be surprising if it was either some kind of specialty shop or the result of an internal rift between the brothers, but the immigration files do not indicate one way or the other. Whatever the

\footnotetext{
29 "Lum Quing," Case File 2135, Box 9, RG 85, NA; "Lum Yick Hen," Case File 3011, Box 20, RG 85, NA.

30 "Lum Lin Oey," Case File 5017/153, Box 86, RG 85, NA.
} 
reason for the second store, it does not seem to have stopped the growth of the first, as grocer and supplier Irvin F. Morrison stated in 1919, "I don't sell them so much anymore, they have outgrown us." 31

The Lum brothers' success allowed them to support more employees in the business and family members at home, and they were able to arrange for these with little trouble from immigration officials. Lum Quing brought a son, George, from China in 1908, who soon entered the family enterprise. ${ }^{32}$ Quing died in 1912 at only forty-eight years of age, but his brother, Lum Sue, carried on the business, bringing in his wife Mary Lum and son Lum Dai Moy on board as members of the firm. Sue also had two daughters, Anna and Flora, and a second son by 1921. Sue's file reports that one of his sons was named George, so it is possible that Sue adopted his nephew after Quing's death in 1912, though he may have simply had a son named George. ${ }^{33}$

Quing's son actually left the firm in the year of his father's death for reasons unknown, possibly as a temporary measure to attend school. ${ }^{34}$ In any case, George sold out his shares to another apparent relative, Lum Foo, an old farmer who sought an easier job because of his health. Sick with tuberculosis in 1919, Foo cited health reasons to explain his trip to China as well. Inspector Gooch even went so far as to advise Seattle's immigration commissioner that Foo was unlikely to survive a roundtrip, but

\footnotetext{
31 "Lum Foo," Case File 5010/608, Box 72, RG 85, NA.

32 "Lum Yick Hen," Case File 3011, Box 20, RG 85, NA. It is unclear from the case files if Yick Hen, called George, was a paper son or not. Officials found no problems in his case.

33 "Lum Sue," Case File 5009/189, Box 56, RG 85, NA.

34 "Lum Yick Hen," Case File 3011, Box 20, RG 85, NA; "Lum Foo," Case File 5010/608, Box 72, RG 85, NA.
} 
the old man defied expectations in 1921, returning to Astoria and bringing an adopted son with him. ${ }^{35}$ Foo was admitted without trouble, but his son, Lum Wui, was interrogated about his home village, family, ancestor's tombs, and various other aspects of his background. The inspection dove into minute detail, asking Wui to identify the oldest man in the village, how many clocks his mother kept in the house, and other trivia characteristic of the investigations that would be conducted in early 1920s Chinese cases. After the extensive questioning, Wui's case was initially deferred for a short time for further investigation, but in the end he was admitted. ${ }^{36}$

Much has been made in Chinese American scholarly literature about the extremely detailed interrogations in Chinese immigration cases of the early twentieth century. In Astoria, these intense sessions were rare before 1920, and even when they did take place, the local inspectors were not as hostile as the exclusion laws allowed. It is only rational to give some leeway when questioning multiple individuals about the positions of clocks and doors in a house on the other side of the planet, and the inspectors in Astoria knew that and acted accordingly, as when Bonham noted "certain, not necessarily vital, discrepancies" in the Low Lin Wong case. ${ }^{37}$ While still following the law, Astoria's inspectors allowed a margin of error for characters such as Lum Wui, not assuming guilt from every mistake. ${ }^{38}$

Despite the death of Lum Quing, his namesake market enjoyed a successful

\footnotetext{
35 "Lum Foo," Case File 5010/608, Box 72, RG 85, NA.

36 "Lum Wui," Case File 5010/412, Box 68, RG 85, NA.

37 "Low Lin Wong," Case File 2629, Box 16, RG 85, NA.

${ }^{38}$ See also "Lum Fong," Case File 5010/409, Box 68, RG 85, NA and "Seid Tong," Case File 4382,
} 
trade at least into the 1920s, and its suppliers, two white grocers by the names of Irvin F. Morrison and K. Osburn, expressed their respect for the company and its owners. Both willingly testified for members of Lum Quing in the immigration office, Morrison doing so on multiple occasions. ${ }^{39}$ Morrison characterized Lum Quing's son as "particularly bright," and in the era of the automobile's infancy he boasted about the car Lum Sue owned and delivered goods in. ${ }^{40}$ Even when Lum Quing and Brother had expanded beyond his own company's supplying capacity, Morrison spoke of his Asian colleagues as allies rather than threats. "We consider them pretty reliable men," he summarized in $1910 .^{41}$ A banker, a doctor, and even inspector Bonham were inclined to agree on record, the latter writing favorable recommendations for both Lum Sue and his daughter Anna.

Lum Quing and Lum Sue were literally not the only Lums on the block vending American-style groceries. Lum Sing Brothers and Company operated from 277 Bond Street, in between the American Grocery Company and Lum Quing and Brother. Lum Sing's was a small operation, with only two partners besides the owner, they being his wife, Ng Lai Seem, and brother in China, Lum Fook Sing. The company rented building space from Joseph Gibler, a music store owner and

\footnotetext{
Box 32, RG 85, NA.

${ }^{39}$ For grocers' testimonies see "Lum Quing," Case File 2135, Box 9, RG 85, NA; "Lum Foo," Case File 5010/608, Box 72, RG 85, NA; "Lum Yick Hen," Case File 3011, Box 20, RG 85, NA; "Lum Lin Oey," Case File 5017/153, Box 86, RG 85, NA; and "Lum Sue," Case File 5009/189, Box 56, RG 85, NA.

40 "Lum Yick Hen," Case File 3011, Box 20, RG 85, NA; "Lum Sue," Case File 5009/189, Box 56, RG 85 , NA.

41 "Lum Quing," Case File 2135, Box 9, RG 85, NA.
} 
sometime client of his tenants. Little is mentioned of Lum Sing in the records, but he had no trouble with the Chinese inspectors. ${ }^{42}$

On the other side of Lum Quing and Brother, at 399 Bond, sat the Astoria Restaurant, another Chinese business in good standing. Created in 1903 by Wong Yuen, this establishment also received relatively little attention in the immigration files, and despite one incident of employing an alleged merchant as a dishwasher, the Astoria Restaurant was held in extremely high regard by inspector Larner, a sentiment that the local white population seems to have shared. Larner wrote of his fondness for the eatery, reporting that it was "conducted in the American style, and caters to white people and is one of the principle[sic] restaurants in this city, with ample evidence of enjoying a remunerative custom, and well adapted to the wants of all its patrons." He went on to vouch for the truth of Wong Yuen's statements. The restaurant did good business, as it had become the second largest in the city in only three years, and the sole owner Yuen employed not only four Chinese cooks but also two white servers in a rare reversal of racial economic roles that I have not seen recorded elsewhere in Astoria during this period. ${ }^{43}$ Independent contractors such as plumbers, doctors, lawyers and so on would take Chinese clients regularly, but for a white man to be employed in a Chinese-run firm was uncommon.

Wong Yuen's success as a businessman paralleled his success in the immigration office. Inspector Larner, known for vacillating between harshness and

\footnotetext{
42 "Lum Sing," Case File 5009/57, Box 56, RG 85, NA.
} 
leniency, took unusual pains to assist Yuen's visit to China in 1906. Concerned for Yuen's health, Larner encouraged him to see a doctor before departing. "We don't want you to go away not understanding that your health on your return governs your admission," the inspector advised. Inspectors did not typically attend to such matters-traveling in poor physical condition was commonplace among Chinese applicants, particularly the older ones, and officials were usually content to note that the individual was unlikely to live long enough to return. ${ }^{44}$ Here, though, we see another example of a successful merchant gaining benefits in the immigration office.

Sometimes, when an ill Chinese intended to visit China, he or she actually did die before returning, as was the case with Chan Sing. A tailor, Sing came to the United States in 1873 and had been clothing Astorians since 1884 from a shop at 622 Commercial Street called Wah Sing and Company, later S.M. Chan Company, Incorporated. The immigration files on Sing and his family indicate a high standing with local officials, though in the mid-1890s there is evidence of nine individuals making illegitimate claims to the partnership of Wah Sing. It is unclear whether or not Sing himself was involved in this, or what action, if any, was taken. The business flourished until 1920, when a sixty-six-year-old and partially paralyzed Sing applied to leave the country, and despite having no partners he was able to turn his business over to his family, giving shares to four of his six children. ${ }^{45}$ His two oldest sons,

\footnotetext{
43 "Wong Yuen," Case File 1010/38, Box 42, RG 85, NA.

${ }^{44}$ Ibid.; see also "Wing Chung," Case File 5010/89, Box 61, RG 85, NA.

${ }^{45}$ Chan Sing actually had eight children, from two wives, but two of the children had died before Sing's application.
} 
Quong Chan and H.T. Chan, were well and favorably known to the immigration office. H.T. brought his wife into the country, with whom he had two children of his own by 1920. Quong attended the University of Pittsburgh for an engineering degree. Both boys testified for the immigration file of Fred Wing, which ran for a decade beginning in 1909, and in it inspector Gooch offered high praise. "Quong Chan and H.T. Chan are two thoroughly Americanized Chinese who are trustworthy," he declared, "H.T. Chan has been known to me for several years and I would accept his testimony as readily as that of anyone, either white or Chinese." 46 The Chan family maintained a presence in Astoria in the following generation as well, and it is one of the few that still has members residing locally. So, despite his death in the early 1920s, Sing's quarter century of work laid the foundation for his descendants' success in the United States. ${ }^{47}$

While Chan Sing was the only Chinese tailor in Astoria, many Chinese were in the laundry business, and their firms were not uniformly as popular as Wah Sing. The ability of the Chinese laundries to get customers, however, suggests some acceptance among the general population, and in Astoria the Hong Sing Laundry stands out as the most popular. One of its owners, Leong Hong had lived in Astoria since 1874 , and his partner Leong Do had joined in the firm five years later. ${ }^{48}$ The two showed a strong commitment to their business, overseeing a one-thousand-dollar

\footnotetext{
46 "Fred Wing," Case File 5017/62, Box 85, RG 85, NA.

${ }^{47}$ For more details on the Chan family history, see Liisa Penner, "The Chan/Sing Family," Clatsop County Historical Society, Cumtux 25 (Fall 2005): 2 - 16.

48 "Leung Hong," Case File 5010/108, Box 62, RG 85, NA; "Leong Do," Case File 1010/25, Box 42,
} 
addition to the rear of their building at 1249 th Street early in the 1900s. Later, they relocated to 418 Bond Street, and the owners again added a fifteen hundred dollar renovation in 1917. By 1905 Do could say that Hong Sing was the largest Chinese laundry in the city, employing four additional laborers and bringing in about one hundred dollars a week, a decent amount considering that rent from the Flavel Estate only cost one hundred and twenty dollars per year. ${ }^{49}$ Hong, after whom the business was named, finally bought out Do's share sometime before 1920 and continued to run the laundry himself with three hired hands, making roughly four thousand dollars in gross revenue in 1919, a steady seven hundred dollar profit.

An educated man, Hong had been superintendant of the local Chinese school for four years and lived a full life by 1920, and one might expect him to consider retirement on his trip to China that year. Instead, Hong showed no signs of abandoning his company, and the seventy-year-old's stated purpose in traveling was to find a wife and continue his family name. Bonham strongly supported the septuagenarian's quest, and the inspector assured his superiors that Hong was "exceptionally truthful." Bonham continued, "This Chinaman, I'm told, contributed to the erection of the Y.M.C.A. building in Astoria, to all the Red Cross drives and has in general conducted himself as a loyal and law-abiding citizen of the United States. He is regarded around Astoria as a fixture or almost a part of the landscape, being one

RG 85, NA.

49 "Leong Do," Case File 1010/25, Box 42, RG 85, NA. 
of the oldest residents now living in that community." 50

The Leong Hong case also illustrates the potential for confusion that existed for Immigration's Chinese inspectors, both regarding name similarities and in distinguishing trustworthy and deceptive individuals. There was a second Leong Hong in town, a laborer who applied for a return certificate at the immigration office in 1905. Living at 306 Bond Street, this second Hong's main occupation was running the Yee Yick Restaurant at 3381/2 Bond Street, and he also held interest in the Yee On Company. His standing with the authorities was also quite different from that of his identically-named compatriot, and this application was rejected for three reasons: first, for insufficient proof of property or debts owed, second, because he had previously applied as a merchant, and third, because officials distrusted the members of the Yee On company. ${ }^{51}$ Unlike the first Leong Hong, the second was not able to leverage his social reputation in the immigration office.

Immigration officials, in fact, were suspicious of the Yee On Company, and its name was a red flag in any applicant's case. In 1914 there was a Leong Shing, a laborer boarding with Yee On, who sought to replace a lost certificate of residence. Leong Hong, the elderly laundryman, actually testified for Shing, along with Leong Yip, but in the end Shing's application was denied based on his inability to provide vital information that matched official records. Such a case could very well have cast doubt on the character of the witnesses, but for whatever reason Hong at least seems

\footnotetext{
50 "Leung Hong," Case File 5010/108, Box 62, RG 85, NA.
} 
to have maintained a good standing with Immigration despite the evident deceit of the applicant he testified for. ${ }^{52}$ So, the poor status of a firm could be an obstacle for certain affiliated individuals, yet did not necessarily override the good image of those already with an upstanding reputation. In this case, Hong's status as a "good" merchant preponderated over his involvement with Shing, while Shing's status as a laborer offered no assistance in dealing with the inspectors and left him vulnerable to the suspicion attached to Yee On.

The Quong Yin Kee Company ${ }^{53}$ started in Astoria in 1883, thanks at least in part to Leong Yip, and in 1894 it changed to Yee On, headquartered at 306 Bond Street. Thanks to its history in the community, the firm was well-connected by the 1900s, and members were able to call upon numerous witnesses both Chinese and white, including grocer and supplier Irvin Morrison, landlord and former butcher Isaac Bergman, and Captain E.P. Parker, who hired cooks from Yee On. ${ }^{54}$ This support did not impress Inspector Bonham, who complained in 1910 of the "reprehensible methods too often resorted to in Chinese cases in this city" involving "leading citizens" signing affidavits with little concern for the truth. ${ }^{55}$ Trouble with the firm is first recorded in 1905, when Leong Hong and Leong Ling simultaneously applied for laborers' return certificates for overseas travel. Ling, like Hong, had

51 "Leong Hong," Case File 1010/22, Box 42, RG 85, NA.

52 "Leong Shing," Case File 3684, Box 27, RG 85, NA.

${ }_{54}^{53}$ Also called the Quong Yuen Kee Company in "You On," Case File 1009/90, Box 41, RG 85, NA.

54 "Leong You," Case File 4836, Box 36, RG 85, NA; "You On," Case File 1009/90, Box 41, RG 85, NA.

55 "Fong Hong," Case File 1896, Box 6, RG 85, NA. 
applied just two months earlier as a merchant and was denied, and here his case was dismissed with the same aforementioned rationale that ended the Hong case. ${ }^{56}$ Little commentary was attached to either case, but inspector Larner made it clear that he distrusted Yee On.

Larner's suspicions of Yee On were corroborated four years later when it was implicated in smuggling immigrants across the border from Mexico. ${ }^{57}$ In 1907 , inspector Bonham confided that a number of Yee On men were in fact laundry workers, "several of whom have been found to be recalcitrant, and untruthful," but the inspector initiated no move against the firm, as he believed Yee On to be operating a legitimate trade aside from their more questionable pursuits. ${ }^{58}$ He was also waiting to collect more evidence of the members' illegal activities, which took about two more years. In 1909, Yee On's alleged bookkeeper Fong Hong was reported to be actually working in a nearby laundry, and Bonham investigated leads on several others, including Leong Chee and Leong Wing. Chee, a Yee On co-founder and former member, had already been denied a merchant's return in 1907, and on a tip that he had returned anyway against the law, Bonham paid a visit to the laundry where Chee worked. Caught by surprise, Chee botched an attempt to secretly pass an address book to a friend, prompting Bonham to search Chee and his room. The book was filled with addresses from Mexico, and Bonham's search produced about twenty-five

\footnotetext{
56 "Leong Hong," Case File 1010/22, Box 42, RG 85, NA; "Leong Ling," Case File 1010/23, Box 42, RG 85, NA.

57 "Leong Chee and Leong Wing," Case File 1902, Box 7, RG 85, NA.

58 "You On," Case File 1009/90, Box 41, RG 85, NA.
} 
incriminating letters between Mexico and the United States indicating that Chee had indeed entered the country on the sly, as had many others, from Ensenada, a port town in Baja California. The letters depicted Ensenada as an uninhibited gateway to the country where virtually no inspection of immigrants' documents took place and Chinese could cross the border "via any way they wanted." Some letters detailed which specific trains to take in order to cross the country without being apprehended by authorities. "It is my opinion that the Chinese at the Yuen Chung laundry and those of Yee On Co. have been more or less associated with those implicated in bringing Chinese fraudulently and surreptitiously into the country," Bonham asserted. ${ }^{59}$ Leong Wing, another suspect, had also been spotted at the laundry during Chee's arrest, but fled immediately. Astoria's officials could do little about all of this besides maintaining extra vigilance toward businesses like Yee On. The company did not last long; it went bankrupt around 1916. In 1920 You On, one of the "few bona fide merchants" of Yee On, sailed for China with no intention of returning, marking the end of the firm. ${ }^{60}$

While the Yee On Company kept connections across North America, the Wing Yuen Company, another suspect firm, had members spread throughout the Pacific Northwest. Apparently a typical cannery contracting and Chinese merchandise

\footnotetext{
59 "Leong Chee and Leong Wing," Case File 1902, Box 7, RG 85, NA. From the confiscated letters it seems that Chinese were taking trains directly from Ensenada across the border, but it is not clear which trains they took or where exactly they crossed into the United States. See also Erika Lee, At America's Gates: Chinese Immigration During the Exclusion Era, 1882 - 1943 (Chapel Hill, N.C., 2005), 158 - 159; Lee describes a similarly unregulated situation at the southern border, which one official called "a joke, a hollow mockery."
} 
combination, Wing Yuen had its origins in the Sun Yuen Lung Company, the latter having gone bankrupt in 1903 or 1904, at which point several core members reformed into Wing Yuen. ${ }^{61}$ Despite its relatively large size, with thirty-seven members in 1896 and thirty-four in 1901, the immigration files are largely quiet about Sun Yuen Lung, except in the case of Go Yong King, who tried to gain admission to the country as a merchant of the firm in 1908, several years after Sun Yuen Lung's closure. He was duly arrested. ${ }^{62}$

Documentation shows that the members of Wing Yuen were generally more tactful than their clansman Go Yong King, and while he was figuratively out of touch, they were literally so, suggesting that many of the members pursued unrelated work interests. Inspectors were suspicious of such scenarios, as Chinese would claim merchant status with a company and then take whatever manual labor work they could find. In 1910, one firm member testified that of his twenty-one partners, only one resided in Astoria and worked in the business. Of the remaining twenty, five were in China, two in Portland, one in Nestucca, three in Ilwaco, and five at various unnamed canneries; one kept a restaurant in Yakima, one ran a post-card store,

\footnotetext{
60 "You On," Case File 1009/90, Box 41, RG 85, NA.

${ }^{61}$ Many dates in this text are approximate due to the incompleteness of the records, but also because Chinese witnesses used a different calendar, so the inspectors themselves were not always sure what dates were being given.

${ }^{62}$ Records of Chinese Arriving, Astoria, Oregon, from Oct. 1st, 1893 to July 11, 1903, Box 6, Portland District Office, Records of the Immigration and Naturalization Service, Record Group 85, National Archives and Records Administration-Pacific Region (Seattle); "Go Yong King," Case File 1528, Box 2, RG 85, NA.
} 
another was dead, and the last was in an unknown location. ${ }^{63}$ These statistics, moreover, fluctuated rapidly, a likely symptom of both the itinerant work patterns of many Chinese immigrants and the rapid turnover that characterized firms like Wing Yuen. A different firm member had offered another account of the shareholders' whereabouts two years prior, one that showed a similar pattern but different specifics, including one in Sumas, four in Portland, two in China, and so on. ${ }^{64}$

A youthful member of the firm, Go Song had only been in Astoria since 1899 but was well known by the white community thanks to his habit of going with his compatriots to translate at banks and stores. His positive image came under scrutiny in the summer of 1910, however, when he suddenly disappeared; the timing of Song's departure was unfortunate, as Wing Yuen manager Go Howe had just been arrested for boarding two illegal aliens at the company's living quarters. Song stayed away for most of the summer, and since he was one of the few Wing Yuen members actually involved in the firm's operations, the inspectors speculated that he was involved in the smuggling. However, they found no evidence indicating as much upon his return. The trip, he explained, was for debt collection at an assortment of regional locations, a plausible alibi considering the extended network that Wing Yuen's men comprised, and the sort of thing that inspectors wanted to hear, since it was an activity regarded as fit for a merchant. ${ }^{65}$

\footnotetext{
63 "Fong Chin Chong," Case File 2200, Box 10, RG 85, NA.

64 "Go Chow," Case File 1519, Box 2, RG 85, NA.

65 "Fong Chin Chong," Case File 2200, Box 10, RG 85, NA.
} 
Unlike Go Song, Ko Hing's story did not sway the inspectors at all after he left town, as he went to work in a cannery after claiming student status. The nephew of Hip King, Wing Yuen's self-described bookkeeper and assistant manager, Hing entered the country in 1915 as a student but dropped out shortly after enrolling in the public Shively School. Questioned about his "vacation," he first declared that he was taking a break to earn some money, but later testified that he had gone to a cannery in Alaska for his health, helping at times with the books and other general work, but not as a paid employee. The Immigration Commissioner in Seattle reported a high frequency of similar statements from other Chinese who abandoned their studies for cannery work, and in this case all involved officials agreed that Ko Hing was not really a student, based on his poor school attendance and lackluster efforts in the classroom. Officials in Washington D.C., who were sometimes consulted in problem cases, ordered his arrest, while from Astoria Gooch reasoned that Hing might turn up in the local gambling joints. In Portland, Barbour waxed sarcastic: "it is not at all unlikely," he averred, "that with the return of the canning season next summer, Ko Hing's health will be so impaired that only another outing at Nushigak with its incidental duties will restore him for his assiduous pursuit of knowledge during the winter months." ${ }^{66}$ Hing's file does not relate what became of the "ubiquitous studentcannery-hand." Cases like this underscore the ease with which Chinese applicants could renege on their avowed occupations once inside the United States, giving

\footnotetext{
66 "Ko Hing," Case File 4193, Box 31, RG 85, NA. Problem cases were sometimes reported to officials
} 
officials good reason to question those claims, as well as the difficulty facing government officials who attempted to keep track of immigrants in their wide-ranging pursuits.

One way Astoria's Chinese inspectors focused their work was by monitoring the 300 block of Bond Street, the location of the Yee On, Ark Wo, and Dock Lung companies. Ark Wo was not a large firm, having seven partners in 1908, but it is significant because of the presence of Lum Ah Quinn, the prostitute lodger and sometime interpreter who inherited the firm after the death of its founder and namesake. Given Quinn's eventual deportation it is not surprising that the few files related to Ark Wo charge its members with fraud. For example, Lum Yook, who lived at Quinn's establishment, constructed a shoddy case for a return certificate preceding a trip overseas in 1908. Since Chinese laborers were required to have $\$ 1,000$ in property or outstanding debts in the United States in order to obtain a return certificate, the usual practice was for applicants to make loans to friends or coworkers. Yook described a series of three loans he had made totaling $\$ 1,030$, but it quickly became evident that no such transactions had taken place. Yook, his friends, and alleged witnesses simply did not agree when questioned separately on the locations, currencies, or methods of the loans, and the entire scheme fell through. ${ }^{67}$ A second attempt to circumvent the law that marred the Ark Wo Company in 1908 involved Wong Hing Fow, an avowed merchant. Trouble arose from records

in Washington, D.C. 
that plainly showed that Hing Fow had previously died in San Francisco. Lum Quinn, the star witness of the case and the applicant's alleged manager, stepped in to explain that this was an entirely different Hing Fow from the one recently deceased. Once again, though, his story did not convince Bonham, raising rather than quieting doubts about Hing Fow's legitimacy. After only one session of questions the inspector wrote, "The attempted fraud in this case is so clear and palpable as to make an extended comment unnecessary." With little hope of the application's approval, Quinn changed tactics and tried to distance himself from Fow, claiming that Fow had long since ceased affiliation with Ark Wo; but Bonham did not buy that either, and after the case had closed Quinn admitted to concocting a ploy to assist Fow, "adding that he guessed it was impossible to fool the Immigration." 68

Lum Quinn's own file, mentioned earlier, was recorded a decade after the Lum Yook and Wong Hing Fow cases and shows that he did not in fact stop trying to fool Immigration, nor did his success rate improve noticeably. It seems rather un-academic to write off Quinn as lacking intelligence, but it is also hard to justify the apparent neglect of thoughtful preparation that Ark Wo associates displayed in their dealings with the authorities. Not only did their deceptions quickly fail, but the impetus for the deceit in the first place is questionable. Myriad other case files testify to the possibilities of satisfying the local Chinese inspectors, by either finding a way to follow the legal protocol or composing a story that persuasively suggested such

67 "Lum Yook," Case File 1551, Box 3, RG 85, NA. 
action. Surely the methods for effectively appeasing the government's bureaucratic controls were no secret in Chinatown, especially to individuals like Quinn who actually had experience working in the local immigration office. Puzzling as it may seem, members of Ark Wo were not the only ones making these mistakes, so perhaps there was a shared expectation that the inspectors in Astoria would not carry out rigorous investigations, or perhaps figures like Quinn played dumb in certain cases to build a false image of ineptitude as a cover for more carefully devised plans. Whatever the reason, a small number of individuals seem to be responsible for instigating a disproportionate amount of the fraud that the Chinese inspectors discovered.

Dock Lung, another Chinese company that warranted close monitoring during the early twentieth century, was also dominated by a single individual. Wong Kee was one of the older residents in Chinatown by the 1910s and an influential local entrepreneur; in fact, he was one of the most economically successful Chinese to find himself at odds with the immigration office, an exception to the inspectors' usual good relations with successful merchants. Kee managed the Dock Lung Company until 1911, when he bought it out with his own firm, Wong Kee and Sons. Both firms sold Chinese goods and dealt in cannery labor contracts, Kee himself managing those for August Larson's Altoona Packing Company. Kee also opened a store called the Oriental Bazaar at 623 Commercial Street, next door to the Wah Sing tailor shop,

\footnotetext{
68 "Wong Hing Fow," Case File 1505, Box 2, RG 85, NA.
} 
ostensibly a good location to break into the larger market of white customers. In 1919 he was hoping to help his son open another store in Vancouver, British Columbia.

Kee actually owned the building that housed his namesake business, a rare achievement for a Chinese firm during that era. In fact, Kee owned the entire corner of 9 th and Bond by 1919, renting space to a pool hall, a barber, a restaurant, boarders, and the Bow On Association. Business trips took him to China every few years, and into the 1920s Kee was traveling across the country researching commodities. ${ }^{69}$

Wong Kee caused considerable concern in the immigration office with his sizeable social influence and generally uncooperative stance toward the authorities. His position as a labor contractor and company manager automatically ranked him among Chinatown's elite, and it appears that his connection with the Bow On Association, to which he rented building space, was significant as well. Bow On was not quite a full-blown tong; according to Sylvia Sun Minnick, Bow On was a branch of the Kong Chow Association, the latter being one of the original Chinese "Six Companies" in San Francisco. Minnick ominously describes Bow On as an "enforcement unit" of the parent organization. ${ }^{70}$ The nature of Kee's affiliation with

\footnotetext{
69 "Wong Kee," Case File 5009/121, Box 57, RG 85, NA.

${ }^{70}$ Sylvia Sun Minnick, The Chinese Communities of Stockton (Mount Pleasant, S.C., 2002), 36; Light, "From Vice District to Tourist Attraction: The Moral Career of Chinatowns, 1880 - 1940," The Pacific Historical Review, 43 (1974), 372; L. Eve Armantrout Ma, "Chinatown Organizations and the AntiChinese Movement, 1882 - 1914," in Sucheng Chan, ed., Entry Denied: Exclusion and the Chinese Community in America, 1882 - 1943 (Philadelphia, 1991), 148 and 155; Marie Rose Wong, Sweet Cakes, Long Journey: The Chinatowns of Portland, Oregon (Seattle, 2004), 27; Chris Friday, Organizing Asian American Labor: The Pacific Coast Canned-Salmon Industry, 1870 - 1942 (Philadelphia, 1994), 64 - 65. Scholars disagree on what exactly the term "tong" refers to, but it is widely used in reference to Chinese associations, frequently in contrast to family associations and district associations. Tongs are often viewed as major players in the vice industries, smuggling, and
} 
this society is not well documented, but his involvement is apparent in a 1922 report from inspector Norene, who asserted that Kee's extended trip to Mississippi in the prior year had stemmed from a threat on his life during the "tong war." ${ }^{71}$ As a man of influence, it makes sense that Kee would play an important role in any society that he might belong to, but besides the threat on his life there is little evidence regarding the extent of his role with Bow On.

Inspector Norene showed by his remarks an awareness of Kee's non-business activities, and it is unlikely that Kee's tong associations increased his trustworthiness in the eyes of the authorities. However, concern for the various Chinese societies present in Astoria did not loom especially large in the immigration office, or at least, the tongs and similar organizations were almost never mentioned in the case files, nor did the inspectors bring them up in their interrogations. More likely to jeopardize Kee's image was an association with illegal immigration, and an unwillingness to reveal to the inspectors when the law was being circumvented. "His reputation for veracity is not the very highest," inspector Reily understated in 1913, upon which Bonham expanded, "Wong Kee has been known to this office for several years as one of the shrewdest equivocators among the Astoria Chinese. ${ }^{72}$ Kee had been attempting

\footnotetext{
violence that took place in Chinese communities. Some scholars, like Light, have treated them as "criminal syndicates." Chan calls them secret societies and equates them to revolutionary "triad" organizations in China, noting that violent conflicts in Chinese immigrant communities were usually labeled "tong wars" regardless of the tongs' actual role. Wong asserts that they were only possibly modeled after triads, and Friday expands tongs to include "a vast array of social, political, and cultural associations among Chinese immigrants."

71 "Wong Kee," Case File 5009/121, Box 57, RG 85, NA.

72 "Wong Gum Yuen," Case File 2102, Box 9, RG 85, NA.
} 
that year to arrange for the arrival of a son, Wong Gum Yuen, from China. After significant discrepancies arose from the testimonies of several individuals, the inspectors came to suspect that the applicant was much older than claimed, and probably not even Kee's son. The alleged father's logic, moreover, was unconvincing. When asked about the applicant's older-than-expected appearance, Kee credited the unusually hot sun in China: it "makes everybody look much older," he explained, stating that, on his own trips to China, the hot sun caused wrinkles and made him look older and "black."73 The officials would have none of it. Gum Yuen was denied admittance to the country. Kee hired an attorney after the decision, but withdrew his appeal before the case reopened. ${ }^{74}$

The Wong Gum Yuen case was an audacious move by Wong Kee, for Kee was considered notorious by the inspectors. In 1905, for example, Kee's nephew, Lum Low, applied as a returning merchant of the Dock Lung Company. He was intending to bring back a son of his own from China. The inspectors discovered, however, that Low had, in fact, initially entered the country as a returning merchant. His "second" return was not granted. ${ }^{75}$ Then in 1909 , Wong Lung applied as a departing merchant as well. Lung did not mention the nature of his blood relation to Kee, but he had been Kee's assistant manager at Dock Lung for seven years prior. Frank Patton, the cashier at the Astoria Savings Bank, was willing to testify in Lung's favor, but Bonham noted

\footnotetext{
${ }^{73}$ Ibid.

${ }^{74}$ Ibid.

75 "Lum Low," Case File 1009/22, Box 39, RG 85, NA.
} 
a conflict of interest in that Patton's bank catered to Chinese firms. Moreover, additional witnesses agreed that Lung actually performed manual labor at a cannerycontrary to his claimed merchant status. Denied a certificate, Lung re-applied as a laborer six months later, this time admitting his part-time cannery work at Altoona, and basing his request on his interest in Dock Lung and a loan to Jung Jow Tow, a gardener. The main testimonies in the case, from Lung, Kee, and Jow Tow, disagreed on basic facts, such as Lung's share in the company and place of residence. He was denied a second time. ${ }^{76}$

Even after these repeated failures and the Wong Gum Yuen debacle, Kee still ventured to testify positively for Wong Hop, a Dock Lung contractor who returned to town from Denver in 1916. This case was problematic from the start as well, for Dock Lung had been out of business for five years by then. Nor could Hop find assistance in a word from Denver's Chinese inspector, who wrote, "We understand that his principle occupation is loafing around alleged Chinese stores and gambling joints in Denver." ${ }^{77}$ Not surprisingly, Hop did not gain return papers either.

In one respect, Wong Kee's willingness to openly position himself and his business enterprises against the executors of U.S. immigration law is strange indeed. His economic success put him near the top of the community in terms of wealth, at least in Chinatown if not in the whole of Astoria, meaning that he had a significant

\footnotetext{
76 "Wong Lung," Case File 1009/21, Box 39, RG 85, NA; "Wong Lung," Case File 1010/12, Box 42, RG 85, NA.

77 "Wong Hop," Case File 4673, Box 35, RG 85, NA.
} 
stake in American society, one which he jeopardized by defying federal officials. ${ }^{78}$ Nor were the offenses against Immigration minor, as Dock Lung was essentially implicated in the illegal transit of aliens into the country, and smuggling could result in several years' jail time and thousands of dollars in fines. ${ }^{79}$ Still, Dock Lung's embrace of smuggling and related activities makes sense for several reasons. First of all, smuggling people across the U.S. border during this era was both relatively easy. Monitoring the borders, and every individual within them, was impossible in the American West. The ninety percent fraud rate that federal officials estimated for Chinese immigration cases suggests that, in Astoria, where most Chinese applications were approved, illegal ventures were successful. ${ }^{80}$ Furthermore, high fraud rates suggest wide acceptance of the practice among Chinese immigrants. Since it seemed in the best interests of their compatriots and them to come to the United States, merchants like Wong Kee were not conflicted. Scholars like Madeline Hsu, Yong Chen, K. Scott Wong and others have emphasized the strong connection that Chinese overseas migrants generally maintained with their homeland, one in which loyalty to relatives and fellow Chinese held a higher moral imperative than obedience to a

\footnotetext{
${ }^{78}$ I have not studied the relative wealth of the rest of Astoria at this point, so I don't know where the Chinese stood in relation to the rest of the community in this regard.

${ }^{79}$ Griffith, "Border Crossings: Race, Class, and Smuggling in Pacific Coast Chinese Immigrant Society." The Western Historical Quarterly, 35 (2004), para. 41, http://www.historycooperative.org /journals/whq/35.4 /griffith.html.

${ }^{80} \mathrm{Hsu}$, Dreaming of Gold, Dreaming of Home: Transnationalism and Migration Between the United States and South China, 1882 - 1943 (Stanford, 2000), 68 and 206; Estelle T. Lau, Paper Families: Identity, Immigration Administration, and Chinese Exclusion (Durham, N.C., 2006), 69.
} 
foreign government. ${ }^{81}$ This attitude was justified further by the federalization of the anti-Chinese movement, with the Chinese Exclusion acts and related laws serving as legally encoded testaments to the U.S. government's offensive stance against Chinese immigrants. Cordial personal relations notwithstanding, even the relatively favored merchants faced the core antagonism of federal policy.

As much as it made sense on one level for Astoria's Chinese to subvert U.S. law in matters of immigration, it remained expedient for them to maintain good relations with local governmental organs. Firms that succeeded in reconciling this tension, or ones that blatantly failed, were relatively easy to deal with in that officials could use the company context as a clear directive in individual cases. In between were a number of firms whose status was ambiguous. The files of members of these firms defy strict categorization due to the mixed messages in their individual or collective testimonies. This ambiguity created large amounts of paperwork at the immigration office as officials tried to make sense of whom they were dealing with. Inspectors commented with delight on firms like Hop Hing Lung that caused little or no trouble, and complained in disgust over companies like Yee On that participated heavily in unlawful activities. In contrast, they remained silent on the apparent duplicity of firms with one foot inside the law and one foot outside, as if the position was taken for granted. So, even while the Chinese assumed some antagonism on the

\footnotetext{
${ }^{81}$ Hsu, Dreaming of Gold, 9 and 12 - 13; Chen, Chinese San Francisco, 96 - 114; K. Scott Wong and Sucheng Chan, eds., Claiming America: Constructing Chinese American Identities During the Exclusion Era (Philadelphia, 1998), 157.
} 
part of the U.S. government, federal officials assumed it on the part of the Chinese, probably adding some superfluous stress to the relationship but not preventing the continued attempts of each camp to further their own goals through cooperation.

One way for a Chinese firm to fall into this ambiguous category between "good" and "bad" was through unfamiliarity. The less officials knew about a business, the less reason they had to suspect problems; but the more reluctant and uninformative Chinese were under questioning, the more it seemed like they had something to hide. Kwong On Chung, for example, was a small Chinese merchandise store located at 358 Bond Street that does not appear frequently in the immigration records. ${ }^{82}$ Founded by Lee Yick Mon in the early 1880s, the company's longevity suggests a successful enterprise, while its low profile indicates an absence of suspicious behavior, at least in regards to matters of immigration. I was unable to find evidence in the case files of any illegal activities by the firm's members, and they were able to secure favorable testimony from the banker Charles Higgins, druggist John Gronholm, and attorney and former customs collector Charles Page, among others. It was impressive support, but still, as much formality as anything else; Chinese were required by law to procure white witnesses, and the inspectors knew that economic interests often prompted witnesses to offer indiscriminately favorable testimonies for their Chinese neighbors.

Despite good witness support, every one of the cases associated with Kwong

\footnotetext{
82 "Lee Sit Gong," Case File 2125, Box 9, RG 85, NA. In the file of Lee Sit Gong, the address is listed
} 
On Chung presented problems. Individual deportment under questioning was one of the largest factors in solidifying a company's credibility with the immigration office, and this is where Kwong On Chung ran into trouble. Lee Wah Sing, for instance, applied for a merchant's return with Kwong On Chung in 1905. The prevalence of apathetic generalities in testimonies from him and his brother convinced Inspector Barbour that Sing's case was "manifestly insufficient," and the application was only approved on a second attempt, in the absence of hard evidence of crime. ${ }^{83}$ Later on, Sing's nephew Lee Sit Gong applied as a merchant's son, and the case was slightly extended due to the confused testimonies of certain witnesses. ${ }^{84}$ Sit Gong's subsequent application a year later required a second attempt before it was approved. Then came the case of Wong Iu Tsun in 1915, an alleged member of the firm who suspiciously did not appear in the company books. When questioned, the manager denied all knowledge of Tsun, and the latter could not even be found around town; finally, a Portland doctor related that the elusive applicant had left for San Francisco. Seattle's immigration commissioner also wrote a letter saying that Tsun's claim to merchant status was probably not legitimate. ${ }^{85}$ The Wong Iu Tsun case file ends without any recorded action taken by authorities in Astoria, however, so it seems that Kwong On Chung avoided an extensive investigation, a victory for the firm considering the issues arising from its members' cases.

as 355 Bond, but in at least one case before and after that the address number is 358 .

83 "Lee Wah Sing," Case File 5010/700, Box 74, RG 85, NA.

84 "Lee Sit Gong," Case File 2125, Box 9, RG 85, NA.

85 "Wong Iu Tsun," Case File 4091, Box 30, RG 85, NA. 
In close proximity to Kwong On Chung, at 363 and 354 Bond, respectively, were Hop Yick Shing Kee and Mee Gin John, two additional companies with ambiguous reputations. Both were slightly larger than Kwong On Chung, and both seem to have been actively involved in the illegal entrance of Chinese into the United States. Hop Yick Shing Kee organized in 1899, and, under the management of the elderly and well-connected Leong Yip, catered to a largely Chinese clientele, boarding workers and vending the standard rice, tea, oil, and assorted merchandise from Asia. In the first two decades of its existence, Hop Yick Shing Kee appears in a series of case files as alternately an active, well-respected business and a shady collection of conspirators. Much of the responsibility for this likely falls on Yip, who, as the man in charge of the company "seemed to be the entire thing" to at least one white businessman. ${ }^{86}$ Aside from his managerial duties, Yip exercised influence in the community as a labor contractor with the Canoe Pass Packing Company cannery in Alaska, and probably for the Union Fisherman's cannery as well, where he purchased work boots for the laborers. ${ }^{87} \mathrm{He}$ also testified for a number of colleagues and relatives, overlapping categories since nearly all of the firm belonged to the Leong clan. Yip's influence, however, burned less brightly in the immigration office, where he was regarded as a bona fide merchant but not an honest man. ${ }^{88}$ It was a precarious situation for both sides, one that highlighted the tension between legality and

\footnotetext{
86 "Leong Yip," Case File 2710, Box 17, RG 85, NA.

${ }^{87}$ Ibid.

88 "Leong Gim Lin," Case File 1428, Box 1, RG 85, NA.
} 
practicality. It also showed the remarkable lack of information in the immigration office, one which the additional members of Hop Yick Shing Kee did little to clarify.

Inspectors did concede the legitimacy of the company's trade, and a reputation as "real" merchants helped Hop Yick Shing Kee members find approval in a majority of their immigration cases. Established merchants of the firm who might otherwise warrant close questioning found little resistance to their travels; interrogations were brief, questions nonconfrontational, and processing quick. The inspectors were so accommodating that when one member left without proper documentation, his return was easily granted based on Yip's explanation that the former's home in China had been hit by a cyclone. ${ }^{89}$ New, incoming members of Hop Yick Shing Kee, generally the younger ones, were in a theoretically less secure position with the immigration office, as they were less well known to the officials, but they did not always experience problems, either. Leong Yick Duck, for example, was exceptional as part of the younger generation but also an original member of the firm, having joined at the age of seventeen. "The Boy" claimed to have been born in San Francisco, ${ }^{90}$ was orphaned at the age of six, and then brought to Astoria by Yip, his father's cousin. After working in the canneries for a period, Yick Duck joined Hop Yick Shing Kee as a bookkeeper and salesman, where he built a reputation as an upstanding citizen; he even registered for the army when America mobilized for World War One. Despite

\footnotetext{
89 "Leong For," Case File 2115, Box 9, RG 85, NA.

90 "Leong Yick Duck," Case File 1009/85, Box 41, RG 85, NA. Stating birth in San Francisco was convenient for many Chinese, since all official records of Chinese births there before 1906 had been lost in the earthquake and subsequent fire that year. Of course, the size of the Chinese population in the
} 
his lack of a birth certificate, he did not encounter any problems with the inspectors, and was granted a nativity certificate in 1925 on the testimony of Chinese witnesses and the strength of his own good standing. ${ }^{91}$

Yick Duck's track record with the law was salient among the younger generation of Hop Yick Shing Kee. Leong Som Tuck, who was likely a founding member of the business, and as co-manager and treasurer in 1910 handled much of the firm's transactions, brought a son to the United States in 1913, Leong Yok Lun. ${ }^{92}$ The young man was admitted without delay initially, but his case file began drawing suspicion from inspector Gooch in 1919, and authorities eventually deported Yok Lun in 1931 for not properly upholding his merchant status. ${ }^{93}$ Another alleged firm member applied for a merchant's return as Leong Fay in 1903, saying he had immigrated as a student several years prior, but his obvious unfamiliarity with the town of Astoria made it clear that he did not actually work at Hop Yick Shing Kee. The witnesses who testified for him did not even recognize his face, plumbing contractor T.J. Sculley admitting that he had only come at the request of his good customer, Leong Yip. ${ }^{94}$

In 1908, Leong Yip had brought his own son into the country. Officials' satisfaction in his legitimate merchant work preponderated over their reservations regarding his other activities, and the benefits attached to his merchant status

Bay Area also made it likely for a U.S.-born Chinese to hail from San Francisco.

91 Ibid.

92 "Leong Som Tuck," Case File 2241, Box 11, RG 85, NA.

93 "Leong Yok Lun," 5009/184, Box 59, RG 85, NA. 
extended to other immigrants. His son, Leong Gim Lin, entered the country in 1908 on testimony from witnesses including the boss of the disreputable Yee On Company. Yip's notoriety spurred an investigation into Gim Lin's identity, but the case proceeded in surprisingly mellow fashion, and Gim Lin was approved without delay in 1908 and again on a 1911 trip to China, the latter being made on merchant status. ${ }^{95}$ It is difficult to assess the significance of Gim Lin's successful immigration without some insight into his real status. He very well may have been Yip's actual son, in which case Yip showed a willingness to work within the law to his own advantage, and the inspectors showed enough restraint to let the case stand on its own merits rather than condemning the applicant for his questionable affiliations. However, there is also a good chance that Gim Lin was not in fact Yip's progeny, illustrating a fact commonly known among the Chinese, specifically, that proper testimony was the key to approval at the immigration office, not actual blood ties or economic status. In either case, sound testimony coupled with whatever credibility Yip possessed from his strong business resume sufficiently counterbalanced the suspicion aroused by his occasional efforts to evade the law, so much so that he was allowed to bring family into the country with relatively little hassle.

The inspectors might have given Leong Yip more trouble for his efforts had it not been for the company across the street, Mee Gin John, whose merchants were busily moving family members internationally at one of the highest rates in the city.

\footnotetext{
94 "Leong Fay," Case File 4791, Box 36, RG 85, NA.
} 
Led by Lum Lop Wy, who attempted to bring at least three sons from China, Mee Gin John affiliates approached Astoria's immigration office with at least seven such applications between 1907 and 1918. In a pattern similar to Hop Yick Shing Kee, Mee Gin John developed a record of illegal immigration practice but managed to gain the inspectors' approval in a high percentage of applications. ${ }^{96}$

No real doubt existed concerning the legitimacy of Mee Gin John as a business establishment, correlating with its success in immigration applications. One of the city's oldest Chinese firms with a history dating back to at least 1872 , it thrived on an almost exclusively Chinese customer base, using a company truck to wholesale vegetables, meat, and sometimes wheat—largely the produce of a rented farm six miles up Young's River. The company was well-known and respected, not only in business circles but also within the immigration office. ${ }^{97}$ Kong Sai Get, the middleaged, wealthy entrepreneur and federal interpreter, was associated with Mee Gin John, while manager Lum Lop Wy's household enjoyed an unusually close relationship with that of August Spexarth, one habitually visiting the other on the host's respective cultural holidays. ${ }^{98}$ Spexarth was part of the local business elite, and his prominence in the case of Lop Wy's son is significant not only because of Spexarth's status but also his absence from other Chinese files, which shows that he did not testify for just

\footnotetext{
95 "Leong Gim Lin," Case File 1428, Box 1, RG 85, NA.

${ }^{96}$ Specifically, five out of every six; ratio is based on twelve case files at the National Archives that centered on a Mee Gin John merchant or merchant's son, with ten gaining approval and only two rejected.

97 "Kong Sue Chong," Case File 5017/88, Box 85, RG 85, NA; "Lum Fong," Case File 5010/409, Box 68, RG 85, NA; "Lum Chack," Case File 3134, Box 22, RG 85, NA.
} 
anyone. $^{99}$

Despite Mee Gin John's economic vigor, exceptional connections, and tolerable success rate in immigration cases, there was only one instance in which a merchant of the firm applied for a return certificate and was approved without suspicion. Lum Chew, who traveled to China in 1909 and returned that same year, had a very uneventful time at the immigration office, and his resulting file is rather short. Seven years later, Chew and a former partner, Lum Dock, also borrowed money to help a laborer and fellow clansman to secure a return certificate by owing him money, and this case was evidently hitch-free as well. ${ }^{100}$ Additionally, several merchant's sons, both native and foreign born, were granted returns without trouble, the most notable of these being Sai Get's child, Kong Sue Chong, and Lop Wy's son, Lum Chack. Sue Chong went on to serve as an Army cook during World War One, then married in China and returned with his wife in $1921 .{ }^{101}$ Sai Get actually testified to help Chack enter the country in 1912, and with the addition of Spexarth's witness it is not surprising that Chack's case went down smoothly. ${ }^{102}$

A number of Mee Gin John cases were ultimately approved but nonetheless suspicious as inspectors weighed their doubts against the merchants' legitimacy. Lum Dock applied for a return as a Mee Gin John merchant in 1913 with all white

\footnotetext{
98 "Lum Chack," Case File 3134, Box 22, RG 85, NA.

${ }^{99}$ Of the immigration case files I inspected at the National Archives in Seattle, only the Lum Chack case involved Spexarth in any way.

100 "Lem Cheong," Case File 4676, Box 35, RG 85, NA.

101 "Kong Sue Chong," Case File 5017/88, Box 85, RG 85, NA.

102 "Lum Chack," Case File 3134, Box 22, RG 85, NA.
} 
witnesses, in a case that appeared fairly straightforward, except for Dock's absence in the company partnership book. The application was re-inspected at Bonham's request, but no incriminating evidence could be found and Dock received his papers. ${ }^{103}$ Another merchant named Lum Sin Yuen was able to make two trips abroad, in 1909 and 1910; the inspectors regarded his travels as relatively innocuous, but it was an earlier case involving Sin Yuen's son that cast doubt on his veracity. Here inspectors had reason to believe that the younger Lum, Bok Sun, had been working in the canneries; Lum Yoke, another Mee Gin John man who served as one of the key witnesses, also carried a reputation of dishonesty. Holes in the main testimonies arose, casting further doubt on the applicant's legitimacy, and finally a coaching letter from Sin Yuen to his alleged son was intercepted during the investigation and the entire case was thrown out. ${ }^{104}$ So when Sin Yuen hastily left the country later that same year without bothering to apply for the proper immigration documentation, the inspectors had reason to question his surreptitious movements. Ostensibly, Sin Yuen had gone to British Columbia for business purposes, and his lawyers had advised that the recent Lum Bok Sun case was sufficient to forego additional investigation of his father. It is not clear why Sin Yuen did not plan ahead and secure the papers he needed to get back into the country, especially if he believed that no real investigation would take place, but for their part the inspectors showed no real interest in Sin Yuen's activities,

\footnotetext{
103 "Lum Dock," Case File 5009/107, Box 57, RG 85, NA.

104 "Lum Bock Sun and Lum Shin Yuen," Case File 1669, Box 4, RG 85, NA.
} 
proving his lawyers correct and keeping his file thin. ${ }^{105}$

No file at all appears for Lum Lop Wy, who nonetheless was present in most Mee Gin John cases, including several involving illegal activity or suspicion thereof. While his son Lum Chack had an easy time with the immigration office in 1912, his next two sons were either less fortunate, less prepared, or less honest in their applications, or some combination of the three. Lum Foon applied in 1915 as a nativeborn Chinese, having at age twenty-five spent the past sixteen to seventeen years in China. Lacking a surefire method for determining the applicant's identity, inspector Bonham made an effort to judge the case based on photographs of an eight-year-old Foon, comparing facial features and showing the prints to witnesses. At least ten witnesses later, it seemed that Foon might indeed be Lop Wy's son. Foon himself, however, proved unable to identify anyone when presented with an old picture of his own family; when told what he was looking at, he did provide a few names, but the inspectors subsequently learned that these individuals were identified in Chinese writing on the photograph. Bonham and his colleagues admitted Foon in the absence of absolutely certain incriminating evidence, but they did not forget him. Two years later, Foon testified for a brother, Lum Pak Quan, to enter the country and the application was rejected. Foon was arrested in 1918 along with an illegal immigrant named Leong Fouie, near the Canadian border, where the former had headed in hopes

\footnotetext{
105 "Lum Sin Yuen," Case File 1820, Box 6, RG 85, NA.
} 
of escaping the wartime draft. ${ }^{106}$

Lum Lop Wy's success in bringing two of three sons into the United States is a notable testament to the strength of his influence as a merchant, as he already had gained attention through his connection to irregular cases. In 1904, Lem Chan approached the office asking for a new residence certificate on the grounds that Lop Wy had accidentally burned the original while cleaning his desk. Lop Wy had been holding the paper for Chan, the applicant asserted, a common thing for a contractor to do for a laborer during the canning season, and the document had been errantly placed in a pile of disposable papers and burned. Chan's testimony was not bulletproof, though; he claimed, for instance, to be thirty-three years old, but also alleged that he had immigrated to the United States in 1871, thirty-three years prior to the case, an unlikely scenario but also a possible misstatement or translation error. ${ }^{107}$ The inspector evidently did not know what to do, as no other witnesses could be found, so he asked Chan and Lop Wy to take a chicken oath, a Chinese practice which involved beheading a bird for the witness to swear on. The Daily Morning Astorian had claimed in a sarcastic 1888 brief that such oaths were taking place at the rate of five per day, contributing to a local chicken shortage, but there is little record of this practice in the immigration case files. ${ }^{108}$ In any case, the oath was deemed sufficient

\footnotetext{
106 "Lum Foon," Case File 4233, Box 31, RG 85, NA.

${ }^{107}$ Dates were particularly problematic in translation; most Chinese followed a lunar calendar, so the translators would often have to calculate the dates themselves.

${ }^{108}$ Daily Morning Astorian, Sept. 13, 1888.
} 
for Chan's situation, and he received a new certificate as requested. ${ }^{109}$

In 1909 another laborer, Lum Kai Ngon, also claimed to have left a certificate of residence with Lum Lop Wy, but this time Lop Wy disagreed. Kai Ngon had received a so-called "red eagle" paper that was supposed to guarantee him landing at San Francisco, an unapproved practice familiar to the inspectors. "I don't know whether I was landed legally or illegally, but the paper was sent to me, and I came on it," was the applicant's only explanation. With this confession, and Lop Wy's denial of the alleged documentation, Kai Ngon was eventually found guilty of illegal entry. Moreover, the investigation implicated seven other individuals of the same offense, suggesting a more extensive smuggling operation than the local officials were prepared to handle. None of the others were actually convicted along with Kai Ngon. ${ }^{110}$ This case did not revolve around Mee Gin John or its trade, but, along with the Lem Chan case and others, it indicates a trajectory of Lop Wy's connections and interactions that did not set him squarely within the law. Fortunately for him, and for other merchants like Leong Yip and Wong Kee, it was possible to succeed as a Chinese merchant in Astoria without a perfect relationship with the immigration office.

The number of firms mentioned so far does not exhaust Astoria's Chinese merchant network during this period. From 1893 to 1903 alone, immigration officials

\footnotetext{
109 "Lem Chan," Case File 1016/38, Box 44, RG 85, NA. Interestingly, Lop Wy did not have a certificate of residence of his own. When asked why he had not gotten one when he entered the country, he simply stated, "I did not care about it."

110 "Lum Ging," Case File 1635, Box 4, RG 85, NA.
} 
documented at least twenty-seven additional companies that I have not addressed in this paper. Of these, the largest were Tai Woh Lung, Wah Tai Lung and Wah Hing Jan, each claiming more than twenty-five partners, along with the Quong Chung, Quong On Chung, Sue Hop, Book Woo, and Kung Wing companies, all of which had at least fifteen members. In all, the government record from that ten-year period shows about four hundred firm partners, a remarkably high number considering that Chris Friday totaled only 561 Chinese in Astoria from the 1900 census. ${ }^{111}$ Granted, not all of the partners in a company always lived in Astoria, and the inspectors were convinced that many were not actually merchants, but this illustrates the influence of the partnerships in the Chinese quarter even in a time when the city's Chinese population had begun to decline.

The influence of businessmen from suspect firms reinforces the presence of class bias among the inspectors that elevated the importance of merchants in the Chinese community. Officials showed leniency toward well-respected merchants even when circumstances warranted suspicion, and individuals like Leong Yip and Lum Lop Wy leveraged this advantage to assist the travels of less prestigious Chinese. Certain merchants lost credibility by being dishonest, and inspectors did come to see some firms as generally untrustworthy, but good business standing could even aid these immigrants. Evading the truth was more forgivable than evading alleged

\footnotetext{
${ }^{111}$ Records of Chinese Arriving, Astoria, Oregon from Oct. 1st, 1893 to July 11, 1903, RG 85, NA. The firms Wah Tai Lung and Tai Woh Lung not only shared comparable titles but also had some similar and even identical names on their member lists.
} 
merchant status. This pattern of relations with successful merchants suggests that the strictures carried out in immigration cases in the 1910s and 1920s were a campaign against Chinese laborers, a continuation of the economically-defined exclusion policy that had begun in the 1880 s. 
Conclusion

Astoria's race relations had reached a new pace by 1924 . Coinciding changes redrew the town's physical, social, and legal landscape, while popular ideas about race on the national scale swung toward a conception of broadly-defined, natural races. ${ }^{1}$ The "Chinese question" no longer loomed as large as it did in the 1880s, and merchants, race relations, and Astoria were essentially different from what they had been a few decades earlier.

Much of the change in Astoria's Chinese-white relations from 1882 to 1924 stemmed from the demographic shifts within the local Chinese population, particularly the decline in laborers coupled with the rise of a merchant class. These demographic changes caused consistent attitudes to manifest in new ways that explain the depiction of race relations in local newspapers and immigration case files.

In the newspapers, anti-Chinese articles aimed at laborers in the $1880 \mathrm{~s}$ gradually gave way to positive reports about Chinese merchants after 1900. These reports reflected the economic and social success of the Chinese merchants as well as the popular demonization of the laborers. Meanwhile, immigration case files show the success of Chinese merchant networks as the 1920s approached, emphasizing the role of class within the Chinese community and the immigration office. Even though the newspapers show an increasing acceptance of Chinese in Astoria and the immigration

\footnotetext{
${ }^{1}$ Mae M. Ngai, "The Architecture of Race in American Immigration Law: A Reexamination of the Immigration Act of 1924," The Journal of American History, 86 (1999), 69 - 70; Matthew Frye Jacobson, Whiteness of a Different Color: European Immigrants and the Alchemy of Race (Cambridge,
} 
case files show increasing difficulty for Chinese in the same locale, both show a persistence of class bias that favored merchants over laborers in the immigrant community.

Chinese Astorians not only contributed to the local economy, but also participated socially and professionally with local whites in the first decades of the twentieth century. The amicability of these relations is not predicted by social models that assume conflict, such as internal colonialism and analogies to the nineteenthcentury South. Social binaries and comparisons to black-white relations help us to understand Astoria's racial tensions, but the sources suggest a much more complex relationship between Chinese and whites in Astoria that incorporated economic and personal factors that Chinese could use to their advantage.

The early 1920s provide a logical stopping point for this thesis because of changes specific to Astoria: the gradual socioeconomic shift away from a Chinese laboring population, the destructive fire in late 1922, and the watershed immigration legislation of 1924. In combination these three factors led to a very different experience for Chinese in Astoria after 1924.

Astoria's canning industry began declining in the late 1880s and by the 1910 s had relocated almost entirely to other locations, heavily reducing the working-class Chinese population in Astoria. Local Chinese cannery workers, numbering around two thousand at the peak in 1886, dipped to about one hundred between 1910 and 
1920 , and fell by 50 percent again in the following decade. ${ }^{2}$ This in turn created a dearth of customers for importers and labor contractors. The Chinese who remained in the 1920s also faced new job competition from Japanese workers for the few remaining cannery positions. The 1920 s also saw the improvement and proliferation of an automatic butchering machine called the "Iron Chink," which replaced some of the highest-paid cannery workers. ${ }^{3}$

On December 8, 1922, a fire broke out in the very early morning hours in the basement of a restaurant and burned until the middle of the day, destroying thirty-two blocks in the core of the city. The accident was a repeat of the 1883 fire that burned the downtown area in a similar fashion; the raised, wooden sidewalks allowed the flames to spread easily and defy containment, as the design had not been changed after the first blaze. The second fire inflicted even more damage than the first, and panicked citizens resorted to dynamiting buildings to create fire breaks after collapsing structures took out the water lines. All told, an estimated twelve to fifteen million dollars in damage was done. Twenty-two Chinese firms were ruined, including successful operations such as Hop Hing Lung, Wah Sing, and Mee Gin John. Only six of the twenty-two had resumed operation by the end of February

\footnotetext{
Caucasian, Negroid, and Mongoloid.

${ }^{2}$ Chris Friday, Organizing Asian American Labor: The Pacific Coast Canned-Salmon Industry, 1870 1943 (Philadelphia, 1994), 58 - 59 and 75; Clatsop County census, Oregon, Fourteenth Census of the United States, (Washington, D.C., 1920), Microfilm, Oregon Historical Society collections.

${ }^{3}$ Steen, "Expanding Context: A Look at the Industrial Landscapes of Astoria, Oregon, 1880 - 1933" (M.A. thesis, Portland State University, 2009), 147; Friday, Organizing Asian American Labor, 104 105, 84 - 85. Steen notes that the large size of Columbia River salmon prevented extensive implementation of the Iron Chink in the area.
} 
$1923 .^{4}$

While the city and its Chinese quarter struggled to recover from the fire of 1922, Congress passed the Immigration Act of 1924, its strictest immigration measure yet. Described as a "triumph of eugenic logic," the legislation implemented nationalorigins-based quotas and summarily brought all Asians under the umbrella of exclusion policy while further curtailing Chinese prospects of entering the country. ${ }^{5}$ The law set the yearly quota for Chinese immigrants at 105, re-defined merchant status to include only international trade, and increased the difficulty of immigrating for Chinese women. ${ }^{6}$ Estelle Lau also marks 1924 as the point when the enforcement of immigration law finally ceased to fluctuate. In Astoria, interrogations became longer and more detailed as well, further blocking immigration. ${ }^{7}$ Canada enacted in 1923 its first law excluding Chinese immigrants, putting up a barrier against the common practice of sailing to Vancouver to avoid U.S. immigration strictures. ${ }^{8}$ National immigration figures for Chinese dropped more than 70 percent from 1924 to 1925 and continued to fall until the 1940s. ${ }^{9}$ Of the small number that did enter the United States after 1924, few had an incentive to go to Astoria with its declining

\footnotetext{
${ }^{4}$ U.S. Department of Labor, List of Chinese Firms Burned Out in Fire of 12/8/1922, Clatsop County Historical Society collection. Short accounts of the 1883 and 1922 fires are found in Karen L. Leedom, Astoria: An Oregon History (Pittsburgh, 2008), 124 - 127 and 82 - 84.

${ }^{5}$ Jacobson, Whiteness, 87; Lucy Salyer, Laws Harsh As Tigers: Chinese Immigrants and the Shaping of Modern Immigration Law (Chapel Hill, N.C., 1995), 245.

${ }^{6}$ Hsu, Madeline Y., Dreaming of Gold, Dreaming of Home: Transnationalism and Migration Between the United States and South China, 1882 - 1943 (Stanford, 2000), 66 and 96.

${ }^{7}$ Estelle T. Lau, Paper Families: Identity, Immigration Administration, and Chinese Exclusion (Durham, N.C., 2006), 103.

${ }^{8}$ Erika Lee, At America's Gates: Chinese Immigration During the Exclusion Era, 1882 - 1943 (Chapel Hill, N.C., 2005), 179.
} 
economic opportunities and a depleted post-fire state.

Despite their small numbers, Astoria's Chinese merchants continue to be notable, in a historical sense. The merchants not only garnered special favor from the white population and immigration officials, but also played an integral role in the functioning of the local Chinese community. As the records from Astoria show, merchants held power in the salmon-canning industry and the ethnic economy, directed the flow of Chinese laborers, and were pivotal in race relations. Because of the merchants' central position in the community, it is my hope that studies like this will add to the depth to local history as well as the broader conversation about Chinese immigration.

\footnotetext{
${ }^{9}$ Hsu, Dreaming of Gold, 68.
} 
Bibliography

\section{$\underline{\text { Primary Sources }}$}

Chinese Exclusion Acts Case Files, 1891 - 1943, Portland District Office, Records of the Immigration and Naturalization Service, Record Group 85, National Archives and Records Administration-Pacific Region (Seattle).

Clatsop County census. Oregon. Fourteenth Census of the United States. Washington, D.C., Bureau of the Census, 1920. Microfilm. Oregon Historical Society collections.

Field report of Agent Bryon, Sept. 12, 1918, Case 8000 - 71351, Old German Files, 1909 - 1921, Investigative Reports of the Bureau of Investigation, 1908 1922, National Archives and Records Administration, publication number M1085, http://www.footnote.com/image/\#488446.

Records of Chinese Arriving, Astoria, Oregon, from Oct. 1st, 1893 to July 11, 1903, Box 6, Portland District Office, Records of the Immigration and Naturalization Service, Record Group 85, National Archives and Records AdministrationPacific Region (Seattle).

Sanborn Map Co. "Astoria, OR." Sanborn, 1908. Clatsop County Historical Society collection.

U. S. Department of Labor. List of Chinese Firms Burned Out in Fire of 12/8/1922. Clatsop County Historical Society collection.

Newspapers:

Daily Astorian, 1882 - 1973

Daily Morning Astorian, 1885 - 1896

Morning Astorian, 1903 - 1918

Astoria Daily Budget, 1894 - 1917

Weekly Astorian, 1886

\section{$\underline{\text { Articles }}$}

Chia-Lin, Pao Tao. "Contributions of Chinese-American Women in the West: The Case of E.T. of Arizona." Chinese Studies in History 34, no. 3 (2001): 10 - 20. 
Chiu, Herman B. "Power of the Press: How Newspapers in Four Communities Erased Thousands of Chinese From Oregon History." American Journalism 16, no. 1 (1999): 59 - 77.

Clatsop County Historical Society. "Labor Contract for Chinese Workers on the Railroad to Astoria." Cumtux 22 (Spring 2002): 21 - 23.

Griffith, Sarah. "Border Crossings: Race, Class, and Smuggling in Pacific Coast Chinese Immigrant Society." The Western Historical Quarterly 35, (2004): 473 - 492. http://www.historycooperative.org/journals/whq/35.4 /griffith.html.

Heinze, Andrew R. "Schizophrenia Americana: Aliens, Alienists, and the Personality Shift of Twentieth-Century Culture." American Quarterly 55, no. 2 (2003): $227-256$.

Hollinger, David A. "How Wide the Circle of the 'We'? American Intellectuals and the Problem of the Ethnos since World War II." American Historical Review 98, no. 2 (1993): 317 - 337.

Kuo, Joyce. "Excluded, Segregated, and Forgotten: A Historical View of the Discrimination Against Chinese Americans in Public Schools." Chinese America: History \& Perspectives (2000): 32 - 48.

Law, Duncan. "The Two Careers of Martha." Cumtux 18, (Summer 1998): 2 - 14.

Light, Ivan. "From Vice District to Tourist Attraction: The Moral Career of Chinatowns, 1880 - 1940." The Pacific Historical Review 43, no. 3 (1974): $367-394$.

Marconeri, Cynthia J. "Chinese-Americans in Astoria, Oregon: 1880 - 1930." Clatsop County Historical Society, Cumtux 13, (Summer 1993): 31 - 37.

Ngai, Mae M. "The Architecture of Race in American Immigration Law: A Reexamination of the Immigration Act of 1924." The Journal of American History 86, no. 1 (1999): 67 - 92.

Pascoe, Peggy. "Miscegenation Law, Court Cases, and Ideologies of 'Race' in Twentieth-Century America." The Journal of American History 83, no. 1 (1996): 44 - 69.

---. "The Chan/Sing Family." Clatsop County Historical Society, Cumtux 25, (Fall 2005): 2 - 16. 
Sarvis, Will. "Gifted Healer: Ing Hay and the Chinese Medical Tradition in Eastern Oregon, 1888 - 1948." Journal of the West 44, no. 3 (2005): 62 - 69.

Tao, Chia-Lin Pao. "Contributions of Chinese-American Women in the West: The Case of E.T. of Arizona." Chinese Studies in History 34, no. 3 (2001): 10 20.

Wang, Wensheng. "Chinese Americans in the Tucson Community." Chinese Studies in History 34, no. 3 (2001): 82 - 96.

West, Elliot. "Reconstructing Race." The Western Historical Quarterly 34, no. 1 (2003): 7 - 26. http://www.historycooperative.org/journals/whq/34.1 /west.html.

White, Richard. "Race Relations in the American West." American Quarterly 38, no. 3 (1986): 396 - 416.

Wunder, John R. "The Chinese and the Courts in the Pacific Northwest: Justice Denied?" The Pacific Historical Review 52, no. 2 (1983): 191 - 211.

$\underline{\text { Books }}$

Aarim-Heriot, Najia. Chinese Immigrants, African Americans, and Racial Anxiety in the United States, 1848 - 82. Urbana, Ill.: University of Illinois Press, 2003.

Anderson, Benedict. Imagined Communities: Reflections on the Origin and Spread of Nationalism. Revised ed. New York: Verso, 1991.

Barkan, Elliot Robert. From All Points: America's Immigrant West, 1870s - 1952. Bloomington, Ind.: Indiana University Press, 2007.

Barnhurst, Kevin G. and John Nerone. The Form of News: A History. New York: The Guilford Press, 2001.

Chan, Sucheng, ed. Entry Denied: Exclusion and the Chinese Community in America, 1882 - 1943. Philadelphia: Temple University Press, 1991.

Chen, Jack. The Chinese of America. San Francisco: Harper and Row, 1980.

Chen, Shehong. Being Chinese, Becoming Chinese American. Urbana, Ill.: University of Illinois Press, 2002. 
Chen, Yong. Chinese San Francisco: A Trans-Pacific Community. Stanford: Stanford University Press, 2000.

Choy, Philip P., Lorraine Dong, and Marlon K. Hom. Coming Man: 19th Century American Perceptions of the Chinese. Seattle: University of Washington Press, 1995.

Couch, Bob. "Family of George Hutcheon \& Jane Gall." Hosted by RootsWeb. http://freepages.genealogy.rootsweb.ancestry.com/ bobcouch/hutcheons/.

Daily Astorian, The. "About." http://www.dailyastorian.com/site/about/.

Daniels, Roger. Asian America: Chinese and Japanese in the United States since 1850. Seattle: University of Washington Press, 1988.

---. Guarding the Golden Door: American Immigration Policy and Immigrants since 1882. New York: Hill and Wang, 2004.

Daniels, Roger and Otis L. Graham. Debating American Immigration, 1882 - Present. Lanham, Md.: Rowman and Littlefield, 2001.

De León, Arnoldo. Racial Frontiers: Africans, Chinese, and Mexicans in Western America, 1848 - 1890. Albuquerque: University of New Mexico Press, 2002.

East Oregonian Publishing Company. "The Daily Astorian." http://www.eopubco.com /papers/da_hist.html.

Federal Writers Project, The Oregon Trail: The Missouri River to the Pacific Ocean St. Clair Shores, Mich.: Scholarly Press, 1972.

Frank, Andre Gunder. ReORIENT: Global Economy in the Asian Age. Berkeley: University of California Press, 1998.

Friday, Chris. Organizing Asian American Labor: The Pacific Coast Canned-Salmon Industry, 1870 - 1942. Philadelphia: Temple University Press, 1994.

Gault, Vera Whitney. A Brief History of Astoria, Oregon, 1811 - 1900. Astoria, Ore.: Vera Gault, 1982.

Hine, Robert V. and John Mack Faragher. The American West: A New Interpretive History. New Haven, CT: Yale University Press, 2000. 
Hsu, Madeline Y. Dreaming of Gold, Dreaming of Home: Transnationalism and Migration Between the United States and South China, 1882 - 1943. Stanford: Stanford University Press, 2000.

Jacobson, Matthew Frye. Whiteness of a Different Color: European Immigrants and the Alchemy of Race. Cambridge, Mass.: Harvard University Press, 1998.

Kirtley, Karen, ed. Astorians, Eccentric and Extraordinary. Salem, Ore.: East Oregonian Publishing, 2010.

Kraut, Alan M. The Huddled Masses: The Immigrant in American Society, 1880 1921. Wheeling, Ill.: Harlan Davidson, 2001.

Lai, Him Mark. Becoming Chinese American: A History of Communities and Institutions. Walnut Creek, Calif.: AltaMira, 2004.

Lau, Estelle T. Paper Families: Identity, Immigration Administration, and Chinese Exclusion. Durham, N.C.: Duke University Press, 2006.

Lee, Erika. At America's Gates: Chinese Immigration During the Exclusion Era, 1882 - 1943. Chapel Hill, N.C.: University of North Carolina Press, 2005.

Leedom, Karen L. Astoria: An Oregon History. Pittsburgh, Pa.: The Local History Company, 2008.

McClain, Charles J. In Search of Equality: The Chinese Struggle Against Discrimination in Nineteenth-Century America. Berkeley: University of California Press, 1994.

McKeown, Trevor W. "Chinese Freemasons." Grand Lodge of British Columbia and Yukon. http://freemasonry.bcy.ca/history/chinese_freemasons/index.html

Mears, Eliot Grinnell. Resident Orientals on the American Pacific Coast. Chicago: Arno Press, 1928.

Miller, Emma Gene. Clatsop County, Oregon: Its History, Legends and Industries. Portland, Ore.: Binfords and Mort, 1958.

Minnick, Sylvia Sun. The Chinese Communities of Stockton. Mount Pleasant, S.C.: Arcadia, 2002. 
Moffat, Riley Moore. Population History of Western U.S. Cities and Towns, 1850 1990. Lanham, Md.: Scarecrow Press, 1996.

Mohr, James C. Plague and Fire: Battling Black Death and the 1900 Burning of Honolulu's Chinatown. New York: Oxford University Press, 2005.

Nash, Wallis. Two Years in Oregon. New York: D. Appleton and Co., 1882.

Noble, David W. The Progressive Mind 1890 - 1917. Revised ed. Minneapolis: Burgess, 1981.

Nord, David Paul. Communities of Journalism. Urbana, Ill.: University of Illinois Press, 2001.

Penner, Liisa. The Chinese in Astoria, Oregon 1870 - 1880. Astoria, Ore.: L. Penner, 1990.

Pfaelzer, Jean. Driven Out: The Forgotten War Against Chinese Americans. Berkeley: University of California Press, 2008.

Raibmon, Paige. Authentic Indians: Episodes of Encounter From the Late-Nineteenth Century Northwest Coast. Durham, N.C.: Duke University Press, 2005.

Ronda, James P. Astoria and Empire. Lincoln, Nebr.: University of Nebraska Press, 1990.

Salyer, Lucy. Laws Harsh As Tigers: Chinese Immigrants and the Shaping of Modern Immigration Law. Chapel Hill, N.C.: University of North Carolina Press, 1995.

Saxton, Alexander, The Indispensable Enemy: Labor and the Anti-Chinese Movement in California. Berkeley: University of California Press, 1971.

Schudson, Michael. Discovering the News: A Social History of American Newspapers. New York: Basic Books, 1978.

Schwantes, Carlos Arnaldo. Columbia River: Gateway to the West. Moscow, Idaho: University of Idaho Press and Columbia River Maritime Museum, 2000.

---. The Pacific Northwest: An Interpretive History. Revised and enlarged ed. Lincoln, Nebr.: University of Nebraska Press, 1996. 
Shah, Nayan. Contagious Divides: Epidemics and Race in San Francisco's Chinatown. Berkeley: University of California Press, 2001.

Shuman, Edwin L. Steps Into Journalism: Helps and Hints for Young Writers. Evanston, Ill.: Evanston Press, 1894. Quoted in Michael Schudson, Discovering the News, 79.

Smith, Courtland L. Salmon Fishers of the Columbia. Corvallis, Ore.: Oregon State University Press, 1979.

Steen, Sarah L. "Expanding Context: A Look at the Industrial Landscapes of Astoria, Oregon, 1880 - 1933." M.A. thesis, Portland State University, 2009.

Takaki, Ronald. A Different Mirror: A History of Multicultural America. Boston: Little, Brown, 1993.

---. Strangers from a Different Shore: A History of Asian Americans. Boston: Little, Brown, 1989.

Tetlow, Roger T. The Astorian: The Personal History of DeWitt Clinton Ireland, Pioneer Newspaperman, Printer, and Publisher. Portland, Ore.: Binford and Mort, 1975.

Turnbull, George S. History of Oregon Newspapers. Portland, Ore.: Binfords and Mort, 1939.

Turner, Frederick Jackson. "The Significance of the Frontier in American History." The Frontier in American History. New York: Henry Holt, 1921. http://xroads.virginia.edu/ hyper/turner/chapter1.html

US Immigration Legislation Online. "1862 Anti-coolie law." http://library.uwb.edu /guides/USimmigration/1862_anti_coolie_law.html

White, Richard. "It's Your Misfortune and None of My Own": A New History of the American West. Norman, Okla.: University of Oklahoma Press, 1993.

Williamson, Samuel H. "Seven Ways to Compute the Relative Value of a U.S. Dollar Amount, 1774 to present," MeasuringWorth. http://www.measuringworth.com /uscompare/. 
Wong, K. Scott and Sucheng Chan, eds. Claiming America: Constructing Chinese American Identities during the Exclusion Era. Philadelphia: Temple University Press, 1998.

Wong, Karen C. Chinese History in the Pacific Northwest. N.p.: Karen Wong, 1972.

Wong, Marie Rose. Sweet Cakes, Long Journey: The Chinatowns of Portland, Oregon. Seattle: University of Washington Press, 2004. 